Children's Growth and Reserch confins shat poor Poverty in Rural Guatemala child growth outcomes in Guatemala are the result of widespread poverty. The Michele Gragnolati better the parents' education and household income, the less likely children are to suffer from mainutrition. Children alșo fare better where community infrastructure (such as piped water and garbage disposall and health 
Policy Research Working Paper 2193

\section{Summary findings}

Gragnolati investigates the extent and determinants of poor child health and nutrition in rural Guatemala, as reflected in attained height.

Exploiting a rich data set on relevant social, economic, ethnic, and geographic characteristics, he estimates the role played by exogenous individual, household, and community covariates in shaping differentials in children's height.

Then he addresses empirical questions ignored in previous anthropometric research, such as the distribution of child stunting across communities and the magnitude of intrafamily correlation of height-for-age outcomes, before and after controlling for observed covariates.

His estimates are guided by the economic model of the family and the proximate determinants framework. $\mathrm{He}$ fits multilevel models to hierarchically clustered data to control for family and community heterogeneity.

His results confirm findings from previous research suggesting that poor child growth outcomes in Guatemala are the result of widespread poverty.

He finds that height-for-age differentials between children of ladino mothers and children of indigenous mothers who do not speak Spanish are larger among children of more educated parents and among children living in communities with better health care facilities.

Estimates derived from multilevel models reveal much clustering of child height-for-age outcomes within families and communities. The models account for most of the community-level variation in child growth patterns but explain only half of the overall intrafamily correlation.

This paper - a product of the Human Development Sector Unit, Latin America and the Caribbean Region - is part of a larger effort in the region to study poverty and human development indicators. Copies of the paper are available free from the World Bank, 1818 H Street NW, Washington, DC 20433. Please contact Michele Gragnolati, room I7-040, telephone 202-458-5287, fax 202-522-0050, Internet address mgragnolati@worldbank.org. Policy Research Working Papers are also posted on the Web at http://www.worldbank.org/html/dec/Publications/Workpapers/home.html. September 1999. (49 pages)

The Policy Research Working Paper Series disseminates the findings of work in progress to encourage the exchange of ideas about development issues. An objective of the series is to get the findings out quickly, even if the presentations are less than fully polished. The papers carry the names of the authors and should be cited accordingly. The findings, interpretations, and conclusions expressed in this paper are entirely those of the autbors. They do not necessarily represent the view of the World Bank, its Executive Directors, or the countries they represent. 


\title{
CHILDREN'S GROWTH AND POVERTY IN RURAL GUATEMALA
}

\author{
Michele Gragnolati ${ }^{I}$ \\ Latin America and the Caribbean Region \\ Human Development Sector Unit \\ The World Bank
}

\footnotetext{
${ }^{1}$ I am grateful to Noreen Goldman, Germán Rodríguez and Anne Pebley for generous support and invaluable guidance throughout all stages of this research. Important suggestions from Narayan Sastry are also acknowledged and greatly appreciated. Most of this work was carried out as a doctoral student at the Office of Population Research of Princeton University. Partial support was received from the National Institute of Child Health and Human Development (NICHD grant R01 HD31327).
} 



\section{INTRODUCTION}

Some progress has been made towards developing an understanding of the causes and consequences of child malnutrition in the development process of poorer countries, but substantial gaps remain in our knowledge about the size and distribution of health and nutrition problems, the determinants of health and nutrient status, the impact of health and nutrition on socioeconomic development, and appropriate nutritional policy design. This paper focuses on the first two issues, namely the extent and the determinants of poor child health and nutritional status as reflected by attained height, in the context of a socially, economically, ethnically, and geographically diverse developing country such as Guatemala.

Special attention is paid to the impact of community factors, which, in recent studies, have been found to affect a number of demographic behaviors and outcomes such as contraceptive use (Entwisle, Casterline and Sayed 1989; Entwisle et al. 1996), poverty (Tienda 1991), the use of modern health services (Pebley, Goldman and Rodríguez 1996), and child survival (Sastry 1996). We also investigate empirical questions that have been ignored in previous anthropometric research, such as the distribution of child stunting across communities and the magnitude of intra-family correlation of height-for-age outcomes, before and after controlling for observed covariates.

Guatemala is among the poorest countries in Latin America. According to the National SocioDemographic Survey, $65.6 \%$ of Guatemalan people lived below the poverty line in 1989. Among these, $38.1 \%$ were below the extreme poverty line. These two figures are higher for the indigenous subpopulation: $86.6 \%$ and $61.0 \%$ respectively (Steele 1993). The poverty of Guatemalans is revealed indirectly by the anthropometric outcomes of their children. The WHO Global Database on Child Growth, based on nationally representative cross-sectional data gathered between 1980 and 1992, covers $87 \%$ of the total population under age five in developing countries (de Onis et al. 1993). It reveals that the prevalence of stunting (low height-for-age) among Guatemalan children below age three in 1987 (57.9\%) was the highest in Latin America. Moreover, among all 79 countries for which there is reliable information available, only Bangladesh, Ethiopia, and India have a higher prevalence of stunting: $64.6 \%$, $64.2 \%$, and $62.1 \%$ respectively. In addition, the prevalence of underweight (low weight-for-age) children in Guatemala was 33.5\%, the second highest in Latin America after Haiti. The prevalence of wasting (low weight-for-height), however, was very low (1.4\%).

The paper is structured as follows. Section 2 outlines the issues involved in using anthropometric outcomes as a measure of child health status. Section 3 describes the main features of the Encuesta Guatemalteca de Salud Familiar (EGSF), which provided the data for our empirical work. In Section 4, we present the results of a descriptive analysis of the EGSF data. Section 5 presents the conceptual framework, the analytical strategy and the statistical methods that we have adopted to model the process 
of children's growth. In Section 6, we describe the variables that were selected to be included in regression analyses of child anthropometry on the basis of theory, previous results and data availability. In Sections 7 and 8 we present and comment on the results of our modeling of child growth in rural Guatemala. Finally, in the conclusions section we summarize the main findings and discuss their policy implications.

\section{CHILD ANTHROPOMETRY}

\subsection{Measurement of Child Health Status with Anthropometric Data}

Among anthropometric measures, weight-for-height, height-for-age and weight-for-age indicators have been utilized extensively. ${ }^{1}$ Height-for-age, weight-for-height and weight-for-age deficits are commonly interpreted as indicative of chronic, acute and total malnutrition respectively. It is very important, however, to recognize that height and weight are measures of growth attainment rather than nutritional status per se (Martorell 1982; WHO Working Group 1986).

The focus of this research is on children's height-for-age outcomes. We use the term malnutrition to refer to the cumulative consequences of inadequate intake of protein energy and micronutrients and frequent infection, as reflected in children's reduced skeletal growth. Given the cumulative nature of the human height process, other information beyond that obtained in a one-time measurement is needed to separate the effects of nutrition from those of genetic factors, past infections and other factors which affect the growth attainment of an individual child. Nevertheless, from a large sample of cross-sectional measurements it is possible to draw meaningful conclusions at the population level about the prevalence and the determinants of children's stunting.

\subsection{The International Reference Population}

The evaluation of growth attainment requires the use of a reference population that allows for normal variation at any age. Although there are obvious ethnic differences between adults, children of different ethnicity have the potential to achieve similar levels of growth attainment in the first few years of life. Many comparative empirical studies have demonstrated the greater importance of socioeconomic factors as opposed to race and ethnicity in determining children's height. Data from India (Rao and Sastry 1977) and Guatemala (Johnston, Borden and MacVean 1973) suggest that ethnic differences in growth potential are minor prior to puberty and that it is during this stage that major differentiation between ethnic groups takes place. Clear differences surfaced during the adolescence period for both sexes:

\footnotetext{
${ }^{1}$ See Martorell and Habicht (1986) for an excellent review of the main research findings on the characteristics of children's anthropometry in developing countries.
} 
Guatemalan and Indian children who were near the $50^{\text {th }}$ percentile of the reference growth charts prior to puberty, ended up near the $25^{\text {th }}$ percentile by the end of adolescence.

The World Health Organization has long recommended the use of a reference population for the assessment of the nutritional status of children (Waterlow et al. 1977; WHO 1979; WHO 1983; WHO Working Group 1986). The emergence of ethnic differences in growth attainment during adolescence justifies the upper limit of 10 years fixed by the WHO on the age for appropriate comparisons with the WHO/NCHS/CDC growth charts.

\subsection{Standard Deviations Scores}

In order to be able to compare the growth attainment of children of different ages by sex, we converted the EGSF anthropometric measurements into three indexes: height-for-age, weight-for-age, and weight-for-height. Using the WHO/NCHS/CDC curves we then expressed the growth attainment of each as standard deviations from the median (z-scores) (Waterlow et al. 1977; WHO Working Group 1986). The standardizing calculations were made with ANTHRO (Software for Calculating Pediatric Anthropometry), Version 1.01, provided by the Division of Nutrition of the Centers for Disease Control and the Nutrition Unit of the World Health Organization.

The z-score measures the degree to which a child's measurements deviate from what is expected for that child, based on a reference population. The formula for the calculation of the height-for-age $\mathrm{z}$ score is:

$$
\mathrm{z}_{\mathrm{i}}=\left(\mathrm{Y}_{\mathrm{i}}^{\mathrm{s}, \mathrm{a}}-\mathrm{H}^{\mathrm{s}, \mathrm{a}}\right) / \sigma^{\mathrm{s}, \mathrm{a}}
$$

where $z_{i}$ is the $z$-score for child $i ; Y_{i}^{s, a}$ is the measured height (in $\mathrm{cm}$ ) for child i of sex $s$ and age $a ; H^{s, a}$ is the median height (in $\mathrm{cm}$ ) for children of sex $\mathrm{s}$ and age a in the reference population; and $\sigma^{\mathrm{s}, \mathrm{a}}$ is the standard deviation in height (in $\mathrm{cm}$ ) for children of sex $\mathrm{s}$ and age a in the reference population.

\section{DATA THE GUATEMALAN SURVEY OF FAMULY HEALTH}

The data for the empirical analysis come from the Guatemalan Survey of Family Health (EGSF) conducted in Guatemala between May and October 1995. The survey focused on a large set of determinants of the health treatment process including the family's economic situation and social support network and women's health beliefs on the nature and causation of illness. The data collection process comprised an ethnographic study of four rural communities, an individual survey of 2872 women of ages

\footnotetext{
${ }^{2}$ See Peterson, Goldman and Pebley (1995) for a thorough description of the EGSF.
} 
18-35, and a set of community surveys, in a sample of 60 rural $^{3}$ communities distributed evenly among 4 departments. The rural population of these departments is highly heterogeneous with regard to ethnicity, language group, economic and social structure, climate and topography.

The individual questionnaire collected information on household composition, background data, birth history, prenatal care and assistance at delivery, infants' and children's health status, contraceptive knowledge and use, marital history, social support, health beliefs, community structure, and economic status.

An extensive community questionnaire obtained information on the presence of various types of health care providers in or near the community, as well as on food prices, infrast-acture, social and religious organizations, and social and political structure of the community. In each community three knowledgeable village informants, one staff/member in the health post or clinic, a private physician, a midwife, and one or two other health providers (including traditional/folk practitioners) were interviewed in Spanish.

Height and weight of children under 5 years of age and the height and weight of the mothers were also collected using standard anthropometric procedures.

\section{IV.DESCRIPTIVE ANALYSIS OF ANTHROPOMETRIC DATA: LEVELS AND DIFFERENTIALS}

\subsection{Prevalence of Stunting, Wasting and Underweight}

Following usual practice in nutritional and epidemiological research, we classify a child as wasted, stunted, or underweight when his or her weight-for-height, height-for-age, or weight-for-age respectively are two or more standard deviations below the WHO/NCHS/CDC reference median.

The prevalence rates of wasting, stunting, and underweight for the entire EGSF sample were $0.7 \%, 61.6 \%$, and $32.2 \%$ respectively. We decided to limit the analysis of the EGSF anthropometric data to height-for-age for two reasons: (1) since weight-for-age is a composite of weight-for-height and heightfor-age, deficits in weight-for-age in Guatemalan children almost entirely reflect deficits in height-forage; ${ }^{4}$ and (2) since the prevalence of low weight-for-height is rare in Guatemala, much larger samples would be needed to explore the correlates of this condition.

\footnotetext{
${ }^{3}$ A community was defined as rural if it contained less than 1800 households. Because the sample entailed selecting an average of 50 women of the specified ages within each community, communities with less than 100 households were replaced with communities from an alternate list.

${ }^{4}$ Keller (1983) used correlation analysis to show that weight-for-height and height-for-age are virtually independent of each other (that is they represent different processes of malnutrition). Regressing weight-for-age on weight-forheight and height-for-age (all expressed in term of standard deviations scores) in several populations with varying prevalence of malnutrition, Keller also found very high coefficients of determination (between 0.95 and 0.98 ). Combining both findings, he concluded that (1) deficits in weight-for-age are a composite of deficits in weight-
} 
The prevalence of stunting among all children in the EGSF survey (61.6\%) is slightly higher than in the 1987 DHS survey and quite a bit higher than in the 1995 DHS survey $(57.9 \%$ and $49.7 \%$ respectively). This higher prevalence reflects the EGSF restriction on rural areas. The prevalence of stunting in rural areas of Guatemala is $62.1 \%$ and $56.6 \%$ respectively in the 1987 and 1995 DHS surveys. ${ }^{5}$ More than half (50.4\%) of the stunted children in the EGSF are extremely malnourished (as determined by height-for-age z-scores below -3.0).

\subsection{Age Pattern of Height-for-Age}

Figure 1 shows the mean z-scores for height-for-age by age group and sex in the EGSF sample. The height-for-age pattern does not seem to vary significantly by sex, a usual finding in Latin America. Following the typical age-pattern observed in developing countries, the average z-score decreases up to age 24 months and then tends to level off (Martorell and Habicht 1986). The negative $z$-scores observed for children at birth indicate that the malnutrition process leading to deficits in height-for-age is likely to have begun prenatally, when inadequately nourished pregnant mothers failed to provide a satisfactory nutritional intake to their fetuses.

\subsection{Ethnic, Education and Income Differentials in Height-for-Age}

Table 1 displays the mean height-for-age and the percentage of children stunted among children of different ethnic, education and income categories in the EGSF sample. The figures confirm the existence of a very marked socioeconomic gradient in child health and nutrition, which was found in previous research in Guatemala (Pebley and Goldman 1995). Note that the prevalence of stunting of children of ladino mothers is less than $50 \%$ while it is almost $80 \%$ among children of indigenous mothers who do not speak Spanish. Differentials are also very important in terms of both mothers' and husbands' education. Note the very low prevalence of stunting ( $8 \%$ ) among children whose fathers have postsecondary education. The mean z-score in height-for-age increases monotonically across the quartiles of the sample distribution of expenditure per capita.

\subsection{Geographical Variation of Stunting in Rural Guatemala}

Table 2 shows the mean $z$-score for height-for-age and the prevalence of stunting by age of the child at the time of interview for both sexes combined, for the complete sample and each of the surveyed

for-height and height-for-age; and (2) studying weight-for-age does not add any additional information to that provided by studying the other two indicators, weight-for-height and height-for-age.

${ }^{5} 1995$ DHS data also indicate that the prevalence of stunting in the rural communities of the four departments surveyed by the EGSF is $63.1 \%$. 
departments separately. Children living in Totonicapán are the most disadvantaged at any age. The overall mean z-score in this department is -3.0 indicating that the average child is severely malnourished.

Table 3 reports the mean z-score and the prevalence of stunting in each of the 60 surveyed communities. There is great variability across communities with the prevalence of stunted children ranging from $20 \%$ (observed in one community in Suchitepéquez) to $88 \%$ (observed in one community in Jalapa).

The variation in height-for-age outcomes across communities is best represented in a box-andwhisker plot (Figure 2). ${ }^{6}$ Mean z-scores vary between -1.1 to -3.5 . The overall median is -2.6 and the overall interquartile range extends between -2.8 and -1.8 . The average $z$-scores in all communities of Totonicapán lie below the overall median. Conversely, the average z-scores in 13 of the 15 communities surveyed in Suchitepéquez are above the overall median. Communities in Chimaltenango and especially Jalapa exhibit the largest variability.

\section{CONCEPTUAL FRAMEWORK AND STATISTICAL METHODOLOGY}

During the last two decades, two major frameworks have been proposed in the social sciences to study the determinants of child health and survival. The first is the Mosley-Chen framework (Mosley and Chen 1984), which has proved very useful for identifying the proximate determinants through which household and community variables operate to affect child health and survival in developing countries. However, the Mosley-Chen framework remains a conceptual model and does not provide any analytical strategy for empirical research to estimate the impact of either the proximate determinants or the socioeconomic variables on child health. The second is the basic microeconomic model of the family (Becker 1981; Singh, Squire and Strauss 1986), which has proved very useful for guiding the choice of explanatory variables in a systematic manner and for interpreting the empirical results (Behrman and Deolalikar 1988).

\subsection{The Mosley-Chen Framework and the Economic Model of the Family}

In their classic analytical framework, Mosley and Chen (1984) identify five categories of proximate determinants of child health and survival in developing countries: (1) maternal fertility (age at childbearing, parity, birth interval, which are affected by reproductive practices); (2) environmental contamination with infectious agents (contamination of air, water and food, skin and soil, and insect

\footnotetext{
${ }^{6}$ Each community is represented by its average z-score. The line in the middle of the box represents the median of the data. The box extends from the $25^{\text {th }}$ percentile $\left(\mathrm{x}_{[25]}\right)$ to the $75^{\text {th }}\left(\mathrm{x}_{[75]}\right)$ percentile. IQ is the interquartile range defined as the difference between $x_{[75]}$ and $x_{[25]}$ (StataCorp. 1997). The lines emerging from the box extend to the upper and lower adjacent values. The upper adjacent value is defined as the largest data point less than or equal to $\mathrm{x}_{[75]}+1.5 \times \mathrm{IQ}$. The lower adjacent value is defined as the smallest data point greater than or equal to $\mathrm{x}_{[25]}-1.5 \times \mathrm{IQ}$.
} 
vectors, which are influenced by hygienic practices); (3) nutrient deficiency (calories, protein, micronutrients, affected by feeding practices); (4) injuries (accidents and intentional injury, which are affected by care); (5) personal illness control (preventive measures and curative treatment, affected by health care practices). All social and economic determinants must operate through the proximate determinants to affect child health and survival.

In the basic microeconomic model of the family, the overall wellbeing of the household depends on the consumption of goods, services and leisure, and on the health of family members. Households maximize their utility function under several constraints: a time constraint for each household member, a budget constraint for the entire household, and a health production function. The health production function relates the health of child to his past health status and the proximate determinants, as outlined in the Mosley-Chen framework. It is a complex relationship that cannot be captured easily by regression analysis based on cross-sectional survey data. Only a series of measurements over time can provide sufficient information to allow reliable judgements on the relative importance of different proximate determinants on growth attainment at the individual level. Health production functions are therefore best estimated with longitudinal data. ${ }^{7}$ The estimation of health production functions is further complicated by the fact that proximate determinants are subject to individual/household choice. Correct estimation of their causal effect relies on controls for simultaneity bias that require information not available in most demographic and health surveys.

\subsection{Reduced-Form Estimation}

The exogenous variables in the microeconomic model are the same as the socioeconomic variables in the Mosley-Chen framework, and the choice variables that appear as covariates in the health production function are the same as the Mosley-Chen proximate determinants (Schultz 1984).

The economic model of the family can be solved to yield a reduced-form equation for health outcomes in which child anthropometry depends only on exogenous individual, household and community characteristics:

$$
\mathrm{z}_{\mathrm{i}}=\mathrm{h}\left(\mathrm{C}_{\mathrm{i}}, \mathrm{C}_{\mathrm{h}}, \mathrm{C}_{\mathrm{c}}, \varepsilon_{\mathrm{i}}\right) \text {, }
$$

where $z_{i}$ is the height-for-age $z$-score for child $i ; C_{i}$ are individual characteristics of the child; $C_{h}$ are household characteristics; $\mathrm{C}_{\mathrm{c}}$ are community characteristics; and $\varepsilon_{\mathrm{i}}$ is an individual specific random disturbance associated with the anthropometric outcome of child $i$.

\footnotetext{
${ }^{7}$ See Cebu Study Team (1991 and 1992) for a description of the conceptual and methodological issues involved in the integration of socioeconomic, behavioral and biomedical variables for studying child health with longitudinal data.
} 
Estimation of the reduced-form anthropometry function $h$ in Equation 1 does not provide information on the biological mechanisms responsible for children's growth deficits, but it does provide a consistent statistical framework within which to estimate the impact on children's health and nutrition of household and community exogenous variables that are generally open to policy intervention. The parameter estimates of the coefficients in the reduced-form equation can be interpreted as the full effects of exogenous covariates, that is their effects not mediated by the proximate determinants (Casterline, Cooksey and Ismail 1989; DaVanzo and Gertler 1991).

Our model specification (Equation 1) ignores the dynamics of child growth. Because of the cumulative nature of the height attainment process, the determinants of current height should include both their current and lagged values (dating back at least to the birth of the child). In using only current information, we are implicitly assuming that household and community characteristics have not changed during the five years preceding the survey and that the relative prices of various food items have remained stable.

\subsection{Methodological Issues}

\subsubsection{Endogeneity}

In a reduced-form estimation framework, caution must be exercised in treating both household resource availability and community endowment of services and infrastructure, especially the concentration of health facilities, as exogenous.

Household resource availability, specifically the component derived from the earnings of the mother, may be endogenous since consumption, leisure and time allocation decisions are jointly determined with child health. For example, if women with more vulnerable children devote more time to take care of their children and less time to work and bring in additional income, the line of causation is not only from household resources to child health, but also the reverse. If this is the case, failure to control for simultaneity will generate biased estimates of the effect of both income and all other covariates that are correlated with income.

Since parents may decide to have fewer and healthier children, household size may also be endogenous (Becker 1981). We control partially for household size by measuring resource availability with household per capita expenditure. 
To determine whether expenditure per capita should be treated as endogenous, we performed a Hausman specification test using the amount of land owned and husband's earnings as instruments. We failed to reject the hypothesis of no endogeneity of expenditure per capita. ${ }^{8}$

The community endowment of services and infrastructure, especially the concentration of health facilities and providers, may also be nonrandom. ${ }^{9}$ Three theories provide insight into how public programs are allocated across population groups: (1) according to altruism theories, public resources are allocated more heavily towards more disadvantaged areas; (2) pressure group theories suggest an allocation pattern of public resources that is directed towards areas with higher demand and more lobbying power; (3) efficiency criteria and externalities may also influence the allocation of government programs so that public resources are placed in order to maximize the overall well-being of the population (Pitt, Rosenzweig and Gibbons 1994). Hausman specification tests for endogeneity in a recent analysis of health care choices in Guatemala suggest that the placement of government health posts and centers in Guatemala is likely to be exogenous (Pebley, Goldman and Rodríguez 1996). However, access to private health facilities and providers may be endogenous since private facilities and providers may concentrate in wealthier areas where children tend to be healthier.

Nevertheless, in our analysis, we treat the placement of all (public and private) community health care facilities and providers as exogenous to child health. Failing to control for the nonrandomness of community services may lead to biased empirical results and erroneous conclusions about the effectiveness of such programs. In theory, the problem of endogeneity with cross-sectional data can be dealt with by the use of instrumental variables techniques. The use of appropriate instruments, that is new variables that are correlated with the endogenous covariates but are not correlated with the error term, would purge the parameter estimates of simultaneity bias. However, in the case of placement of community services, a valid set of instruments is not available from the EGSF data. ${ }^{10}$

\footnotetext{
${ }^{8}$ In the first stage regression, husband's earnings and owned land are significant at the $10 \%$ level and $5 \%$ level respectively. The $\mathrm{R}^{2}$ is 0.20 . The EGSF collected no information on either unearned income or the value of household assets, which would be other valid instruments for household resource availability.

${ }^{9}$ For instance, Frankenberg (1995) notes that several studies of health policies in Indonesia suggest that the distribution of health facilities, both public and private, is related to factors such as population density, level of socioeconomic development, integration into transport networks, and administrative rank, all of which may be related to morbidity and mortality.

${ }^{10}$ If we had data for more than one point in time, we could use fixed-effects estimates to control for the endogenous placement of community services by estimating how the change in local programs affects the change in children's growth. Note that the panel data should not be too closely spaced because short-term program changes are likely to be small and their effect not significant. Rosenzweig and Wolpin (1986) and Pitt, Rosenzweig and Gibbons (1994) have adopted the fixed effects methodology to control for the nonrandom spatial distribution of government programs in the Philippines and Indonesia. Because governments allocated schools and health and family planning programs in more disadvantaged areas first, OLS estimates based on the assumption of exogenous program placement indicate a negative impact of such services on children's growth. Conversely, estimates that control for endogenous program placement by differencing across the two time periods reveal a substantial and significant effect of vernment programs.
} 


\subsubsection{Migration}

Even if services and infrastructure across communities are distributed randomly, individuals may choose to migrate to communities that offer the preferred set of services. In particular, disadvantaged households with unhealthy children may decide to move to areas with better infrastructure and community services, a choice process likely to be reinforced by the fact that better employment opportunities are usually found in the same areas. In the absence of a valid set of instruments to explain migration decisions, we treat the households' place of residence as exogenous to child health. Moreover, since in rural Guatemala there is little migration of families with small children $(96 \%$ of the children in the EGSF sample have spent all their life in the villages where they were born), community characteristics are likely to reflect the environment in which children grew up.

\subsubsection{Clustering}

The multistage clustered sampling design adopted in the EGSF is typical of many demographic and health surveys conducted in developing countries, including the World Fertility Surveys and the Demographic and Health Surveys. In the first stage of sampling, 15 rural communities were randomly selected in each of the four chosen departments. The second stage involved random selection of about 100 households within each community. ${ }^{11}$

The data that we use for our empirical analysis are thus characterized by two levels of clustering: children are grouped within families and families are grouped within communities. The 2963 children for which we have complete information on all the variables that we use in regression analyses come from 1658 families distributed across 60 communities. ${ }^{12}$ In our sample, the number of children per community ranges from 10 to 87 (mean $=49.4$ ). The number of families per community ranges from 11 to 44 (mean $=27.6)$ and the number of children per family ranges from 1 to $4($ mean $=1.8)$.

While the growth experience of children in different communities may be independent of one another, the anthropometric outcomes of children in the same community, especially if they belong to the same family, are likely to be similar since these children share many characteristics when growing up. Thus, a consequence of clustering is that observations in the same group may be more homogeneous than

\footnotetext{
${ }^{11}$ The actual number of households selected in each community varied between 92 and 109.

${ }^{12}$ The structure of the data is slightly more complex since more than one woman was interviewed in a few households. In such cases, children of different families (mothers) belong to the same household. The total number of households for the anthropometry sub-sample is 1636 (in contrast to 1658 families). For the sake of simplicity in modeling, in our statistical framework we treat children of different families (mothers) as if they belonged to different households. In the analysis that follows, family and household are used interchangeably.
} 
observations chosen at random, thus violating the assumption of independent observations that underlies classical statistical analysis.

\subsection{Multilevel Linear Models for Hierarchically-Clustered Data}

The multilevel framework provides statistical techniques specifically designed to account for the data hierarchies that we have just described. Two types of multilevel models are available, variancecomponents models and random-coefficients models, the first being a special case of the second. We estimate both types of models with MLn, a multilevel statistical package developed by the Institute of Education at the University of London (Rasbash et al. 1995). Maximum likelihood estimates (MLE) and restricted maximum likelihood estimates (REML) are obtained via a restricted iterative generalized least squares (RIGLS) algorithm. See Goldstein and Rasbash (1992) for details on the computational procedures.

\subsubsection{Variance-Components Models}

The greater homogeneity of observations in the same group can be modeled by a positive withincluster correlation among anthropometric outcomes of children in the same family and in the same community. Variance-components models correct for the problem of correlated observations by introducing a random effect at each cluster: ${ }^{13}$

$$
z_{i j k}=\beta^{\prime} x_{i j k}+\delta_{i}+\mu_{i j}+\varepsilon_{i j k},
$$

where $z_{i j k}$ is the height-for-age $z$-score for the $k$ th child of the $j$ th family in the $i$ th community; $\beta$ is a vector of regression coefficients corresponding to the effects of fixed covariates $\mathrm{x}_{\mathrm{ijk}}$, which represent observed characteristics of the child, the family and the community; $\delta_{i}$ is a random community effect that represents the deviation of community $i$ 's mean z-score from the grand mean; $\mu_{\mathrm{ij}}$ is a random family effect that represents the deviation of family $i j$ 's mean $z$-score from the mean of community $i$; and $\varepsilon_{i j k}$ is an individual error term that represents the deviation of child $i j k$ 's z-score from the mean of family $i j$.

The random effects $\mu_{\mathrm{ij}}$ and $\delta_{i}$ represent unobserved family and community factors shared between siblings and between children living in the same community respectively. Anthropometric outcomes of children living in the same community (but not in the same family) are correlated because they share the random effect $\delta_{i}$, and anthropometric outcomes in the same family are correlated because they share the random effects $\delta_{i}$ and $\mu_{i j}$. The error terms $\delta_{i}, \mu_{i j}$, and $\varepsilon_{i j k}$ are assumed to be normally distributed with mean zero and variances $\sigma_{c}^{2}, \sigma_{f}^{2}$, and $\sigma_{i}^{2}$ respectively. If $\sigma_{c}^{2}$ is zero, observations in the same community (but

\footnotetext{
${ }^{13}$ This class of multilevel models has been termed variance-components models because the total variance for each response is constant and equal to the sum of the individual, family and community variances.
} 
not necessarily in the same family) are independent. If $\sigma_{f}^{2}$ is also zero, observations belonging to the same family are also independent. If $\sigma_{\mathrm{c}}^{2}$ and $\sigma_{\mathrm{f}}^{2}$ are not zero, the observations are correlated and the Ordinary Least Squares (OLS) assumption of independence does not hold. The variances of the random terms are the additional parameters estimated by variance-components models as compared to OLS linear regression models. To the extent that the greater homogeneity of within-cluster observations is not explained by the observed covariates, $\sigma_{c}^{2}$ and $\sigma_{f}^{2}$ will be larger.

We can use the resulting estimates to assess the extent to which child health is correlated within families and within communities, before and after we have taken into account the effect of the observed covariates $\mathrm{x}_{\mathrm{jjk}}$. The correlations between the anthropometric outcomes of children in the same community and in the same family are respectively

$$
\rho_{\mathrm{c}}=\sigma_{\mathrm{c}}^{2} /\left(\sigma_{\mathrm{c}}^{2}+\sigma_{\mathrm{f}}^{2}+\sigma_{\mathrm{i}}^{2}\right)
$$

and

$$
\rho_{\mathrm{f}}=\left(\sigma_{\mathrm{c}}^{2}+\sigma_{\mathrm{f}}^{2}\right) /\left(\sigma_{\mathrm{c}}^{2}+\sigma_{\mathrm{f}}^{2}+\sigma_{\mathrm{i}}^{2}\right) \text {. }
$$

The total variability in individual anthropometric scores can be partitioned into its three components, i.e. variance among: children within families, families within communities, and communities. By including covariates measured at the individual-, household-, and community-level, variance-components models enable us to explore the extent to which community differences in average height-for-age z-scores are accountable for by factors operating at each level.

\subsubsection{Random-Coefficients Models}

The variance-components models described above allow the level of the response to vary across families and communities (for this reason variance-components models are also referred to as randomintercept models). If we allow the effect of some covariates to vary across families and communities, we obtain a more general class of models called random-coefficients models. For example, we can think of the effect of maternal education on child anthropometry as varying from community to community instead of being fixed across communities. This is equivalent to assuming that the slope of maternal education is a random effect $\beta_{i}$, which we assume normally distributed with mean $\beta$ and variance $\sigma_{\beta}^{2}$, where $\beta$ is now the average effect of maternal education across the surveyed communities.

Under these assumptions, the covariance of the disturbances, and therefore also the total variance at each level, depend on the values of the predictors. The estimator for each group is a weighed composite of the information from that group and the relationship that exists in the overall sample. 


\section{INDIVIDUAL, HOUSEHOLD AND COMMUNITY EXOGENOUS COVARIATES}

The variables included in our analysis have been chosen on the basis of theoretical significance, previous research and data availability. Table 4 provides a list of the variables used in reduced-form estimation, together with their means and standard deviations (for the continuous variables) or the percentage in each group (for the categorical variables) both for the full sample and by department.

\subsection{Individual and Household Characteristics}

Individual-level and household-level covariates in the reduced-form equation described in Section 5.2 (Equation 1) consist of the child's age and sex, mother's ethnicity, mother's height, mother's education, husband's education and household per capita expenditure in the month preceding the interview.

The child's age is included in the model to control for the cumulative nature of the height-for-age variable. Older children's negative z-scores may be larger just because the process of growth retardation has been going on for a longer time (WHO 1986). We include both a linear term and its product with a dummy variable (indicating an age below 24 months) in order to reproduce the observed age pattern of height-for-age outcomes, which decrease over time from birth up to age 24 months and then show a tendency to level off (see Figure 1). The mean age of children in the sample is about 46 months, ranging from 0 to 68 months. We include sex as a covariate in our model to test the hypothesis of no sex differentials in child growth patterns. Children in our sample are equally distributed by sex.

We compare the growth outcomes of children whose mothers belong to three different ethnic/language groups: ladinos (who, by definition, speak Spanish), indigenous who speak Spanish, and indigenous who do not speak Spanish. Previous research indicates that, not only are indigenous people disadvantaged in terms of access to financial and health care resources with respect to ladinos, but also that, within the indigenous population, inability to speak Spanish is a major obstacle towards social and economic mobility. In particular, it is documented that indigenous people who do not speak Spanish are more likely to receive discriminatory treatment by health providers, who rarely speak indigenous languages (Cosminsky 1987; Pebley, Goldman and Rodriguez 1996). Note that $78 \%$ and $39 \%$ of the children in Totonicapán and Chimaltenango respectively were born to mothers who do not speak Spanish. Previous anthropometric research in Guatemala shows that ethnic differences in attained height are reduced considerably when social class and economic status are taken into account (Bogin and McVean 1982; Bogin and McVean 1983; Pebley and Goldman 1995).

Mother's height is used as a proxy both for her genetic traits and health endowment and for unobserved family background characteristics. It also has a direct influence on child height through its association with birthweight (Mueller 1986). Previous research has shown a very strong association between parental and child height in many different countries, the effect of mother's height being 
consistently larger than that of father's height (Barrera 1990, Thomas and Strauss 1992, Lavy et al. 1996). Note that the average height of mothers is highest in Jalapa and lowest in Totonicapán, probably reflecting the poorer living conditions found in the latter department.

Since the mother plays the central role in household domestic activities pertaining to childrearing, maternal education has usually been considered among the most important determinants of child health in developing countries. Mothers of children in the EGSF sample have on average 2.3 years of education. Note that half of the women in Totonicapán have no education.

Husband's education is also likely to affect child anthropometry through the allocation of resources and the ability to use different types of health services more effectively. The majority of husbands in the EGSF sample have attended primary school, although few of them have completed the full six-year cycle. They have on average 3.1 years of schooling. As with mothers' education, average husbands' education is lowest in Totonicapán and highest in Chimaltenango.

Per capita expenditure (measured in quetzals per month) is highest and most variable among communities in Jalapa and lowest and least dispersed among communities in Totonicapán and Chimaltenango.

\subsection{Community Characteristics}

We used two classes of variables to represent the community environment in which children grew up. First, global variables are community indicators collected separately from the main individual questionnaire (Bilsborrow and Guilkey 1987). The global variables we use in our analysis come from the community questionnaire. ${ }^{14,15}$ Second, contextual variables are obtained by aggregating data collected from the individual questionnaire (Bilsborrow and Guilkey 1987; Goldstein 1995). The EGSF design was such that households were selected randomly in each community. Surveyed households are therefore scattered randomly across the community so that contextual variables are likely to be representative of the whole community and not only of selected areas.

The community-level covariates in our study are divided into six groups that aim to capture the different mechanisms through which the community environment can influence child growth: (1) public

\footnotetext{
${ }^{14}$ The only exception is the data on altitude of municipality capitals that were coded from information supplied by the Guatemalan Military Geographic Institute and the National Statistical Institute (Pebley and Goldman 1995).

${ }^{15}$ The EGSF collected information from three key informants in each community. When there was lack of agreement among the answers given by the three key informants, we reconciled the responses as follows. For continuous variables, such as distances and prices, we computed the median value. For ordinal and categorical variables, when possible, we selected the answer on which two informants agreed. When all responses were distinct, we chose the value which fell between the other two in the first case and the answer given by the mayor in the second case.
} 
health infrastructure; (2) modernization; (3) economic structure; (4) food prices; (5) ecological characteristics; and (6) availability of health care facilities and providers.

Covariates related to public health infrastructure in the community include indicators of the prevalence of water connections, sanitation facilities and the presence of infrastructure for garbage disposal. With respect to the first two, we consider as covariates the proportion of households in the community with piped water connections and flush toilets. Most studies have treated water and toilet facilities as household variables. Since we do not have information to test whether these inputs are , simultaneously determined with choices about the health of children in the household, we decided to include them first as community-level variables and therefore as exogenous to the attainment of child height. ${ }^{16}$ With respect to the third, a dummy variable indicates whether there is a public dumpsite in the community. ${ }^{17}$ Communities in Suchitepequéz and Totonicapán are the best and the worst equipped respectively (in the latter department only one per thousand of the surveyed households have tap water, only one percent have flush toilets, and only one of the 15 surveyed communities provides a public dumpsite for garbage disposal).

Measures of modernization include the percentage of households in the community with a television and the proportion of women in the community who have had either formal schooling or adult literacy classes. These variables aim to capture ideational effects on norms and behavior about modern feeding and child care practices.

The economic structure of the community is represented by a set of five variables that capture the degree of accessibility to the local economy, of regular employment opportunities in the agricultural sector, and of accessibility to credit institutions. Overall, communities in Chimaltenango and Totonicapán are the least equipped and communities in Suchitepéquez the best equipped. Another indicator of the economic structure of the community is represented by the total number of people living there as of the 1994 Census. The average community has 2587 inhabitants, the range being between 507 and 9928 . Communities in Totonicapán tend to be bigger and communities in Jalapa tend to be smaller than the remaining communities.

Evidence related to the effects of market prices on child height-for-age is ambiguous. Barrera (1990) found no effect of the price of rice, cooking oil, kerosene or milk on child height in the Philippines. Foster (1990) finds that child height is negatively correlated with changes in rice prices in Bangladesh. Thomas and Strauss (1992) found that, taken together, prices have a significant effect on

\footnotetext{
${ }^{16}$ In the analysis of the proximate determinants, we will add the availability of piped water and flush toilets as household-level covariates.

${ }^{17}$ The presence of a public dumpsite in the community is meant to capture a conscious public health effort by the local authorities.
} 
child height in Brazil. In our analysis we have information on the price of five food items: rice, beans, corn, sugar and salt.

Ecological characteristics include the geographical altitude of the capital of the municipality in which the community is located. Communities in Suchitepequéz and Totonicapán are located at the lowest and highest altitude respectively ( 410 and 2,708 meters on average), a factor that helps to explain why 14 out of 15 communities in the former department have a farm/plantation in their neighborhood and none of the communities in the latter department have any.

The final set of community covariates describes the availability of health care facilities and providers in the community. Our indicators distinguish between the availability of private and public health facilities in the community, the former including hospitals, ${ }^{18}$ clinics and pharmacies, the latter including health posts and centers and IGSS clinics. We also include the total number of doctors reported to work within 20 kilometers of the community.

No variables representing access to educational facilities are included in our analysis because all surveyed communities contain a primary school. No other information on educational facilities was elicited.

\section{REDUCED-FORM ESTIMATION: THE ROLE OF INDIVIDUAL, HOUSEHOLD AND COMMUNITY CHARACTERISTICS}

\subsection{Modeling Strategy}

In order to better understand the effects of individual, household and community exogenous variables, we have fitted several models. Model 1 presents the estimates of univariate models in which height-for-age is regressed against each variable one at a time. The coefficients represent the gross effect of each covariate. Models 2, 3, and 4 include all individual, household, and community covariates respectively. Model 5 includes individual and household covariates only. Finally, Model 6 includes all exogenous variables specified in the reduced-form equation. The data suggest that both mother's and husband's education have a non-linear effect on child anthropometry. To capture the non-linear impact, we model these covariates as categorical variables. ${ }^{19}$ However, in order to further simplify the modeling process, to compare our results with previous empirical work, and to estimate the sensitivity of our results to different model specifications, Model 7 displays the main effects of individual, household and

\footnotetext{
${ }^{18}$ Information from the community questionnaire reveals that while a government hospital is located in the neighborhood of half of the surveyed communities, none of them is actually in the community.

${ }^{19}$ Mother's education is represented in three categories: (1) no education, (2) some primary education, (3) some secondary or higher education. Only three mothers in the sample have higher than secondary education and therefore, for statistical purposes, they cannot be treated as a separate category. Husband's education consists of four categories: (1) no education, (2) some primary education, (3) some secondary education, (3) some postsecondary education.
} 
community covariates when both education variables are treated as continuous variables. ${ }^{20}$ The coefficients in Models 6 and 7 are of special interest since they estimate the correlation between the exogenous covariates and child height-for-age net of many confounding socioeconomic factors.

\subsection{Fixed Coefficients}

The parameter estimates are shown in Table 5 .

\subsubsection{Individual and Household Covariates}

The parameter estimates confirm both the cumulative nature of stunting and the age pattern described in Figure 1: relative to the reference charts, height-for-age $z$-scores decline with age until around two years and then tend to level off. Consistent with previous findings in Guatemala, and Latin America in general, there is no evidence that child growth patterns vary significantly by sex.

Ethnic/language differentials in height are very large when no controls are included in the analysis. Consistent with the figures shown in Table 1, Model 1 indicates that children of indigenous mothers are significantly shorter than children of ladino mothers, the difference being amplified if the mothers do not speak Spanish. The differentials are about halved when we control for household characteristics (Model 3) or for both individual and household characteristics (Model 5). They are, however, still highly significant. They are further halved when we also control for community characteristics (Models 6 and 7). In addition, the difference in height between children of indigenous mothers who speak Spanish and children of ladino mothers is no-longer significant at the $5 \%$ level. Children of indigenous mothers who do not speak Spanish, however, are still significantly shorter than those of ladino mothers. These findings suggest that the worse growth patterns of children of indigenous mothers are for the most part accounted for by the poorer household and community conditions in which they live and that the ability to speak Spanish provides Guatemalan mothers with means of improving their children's heath and nutritional status.

The effect of mother's height on child height is highly significant across all model specifications (P-value $<0.01$ ). The change in the size of the coefficient between Model 1 and Model 3 (from 0.068 to 0.057 ) suggests that mother's height serves as a proxy for unobserved family background characteristics. ${ }^{21}$

\footnotetext{
${ }^{20}$ To see how the effects of parents' education change across model specifications, the estimates based on continuous representation of these variables are also reported in the corresponding columns (within boxes).

${ }^{21}$ Results (not shown here) indicate that the coefficient for maternal education differentials decline by $90 \%$ (primary education) and $20 \%$ (secondary or higher education) after we control for mothers' height. Similarly, the coefficients for paternal education differentials decrease by $160 \%$ (primary education), $35 \%$ (secondary education), and 34\% (post-secondary education). The coefficient for expenditure per capita declines by $20 \%$.
} 
There is strong evidence that children of better educated parents in developing countries are healthier and our results are consistent with this evidence. Although a reduced-form framework does not permit us to infer the mechanisms through which parental education affects child anthropometry, our findings show that these effects are robust to the inclusion of potentially confounding factors at both household and community levels. ${ }^{22}$ Model 1 shows the strong correlation between mother's education and child height observed in the EGSF sample. Roughly, one additional year of formal education is associated with a one-tenth standard deviation increase in anthropometric score. However, a non-linear pattern emerges. In the univariate regression, children of mothers with secondary or higher education are one standard deviation taller than children of mothers with no education (a huge difference). The differential remains substantial and significant when we control for all exogenous covariates. On the other hand, the effect of primary education is reduced by more than three-quarters and is no longer significant when all the variables are included as covariates (Models 6 and 7). The effect of father's education on children's height-for-age outcomes is similar to that of mother's education, although generally smaller in magnitude. One exception is the huge differential in height observed between children of fathers with no education and children of fathers with post-secondary education (1.7 and 0.8 standard deviations in the $\mathrm{z}$-score respectively, before and after controlling for all other factors).

There is some uncertainty in the literature about the size and significance of effects of household resource availability on child anthropometry (Thomas and Strauss 1992; Lavy et al. 1996). Our findings indicate that, when measured in terms of expenditure per capita, household resource availability has a substantial and highly significant effect in Guatemala. Models 6 and 7 indicate that, other variables being equal, children living in families with a per capita monthly expenditure at the $90^{\text {th }}$ percentile $(52.5$ quetzals) are 0.3 standard deviations taller than children living in families with a per capita monthly expenditure at the $10^{\text {th }}$ percentile (9.5 quetzals). ${ }^{23}$

\subsubsection{Community Covariates}

The public health variables are all significantly (individually and jointly) associated with child anthropometry. Improved water and sanitation are expected to be associated with reduced exposure to

\footnotetext{
${ }^{22}$ Since Caldwell's early work in Nigeria (1979), explanations for the independent effect of parents' education on child health and survival have focused on the nature of health beliefs and health care norms and practices, reactions to illness and decision making during illness. Caldwell argues that the schooling process produces a less fatalistic attitude towards life and eventually results in parents' more conscious and more effective efforts toward combating their children's illness. More educated parents are more capable of manipulating the resources that modern medicine makes available. Not only does education provide skills and knowledge to the parents, but it also reinforces their self-confidence and initiative towards modern health care practices. Specifically, parents with additional years of schooling are more likely to know where modern health care facilities and providers can be found, to visit them more frequently and to control the child health care process more effectively.

${ }^{23}$ Such a difference is 43 Guatemalan quetzals, about 8.5 US dollars.
} 
pathogens and better health status. The proportion of households with piped water connections is indeed positively associated with children's health and nutritional status. The effect is reduced when other community variables and/or household variables are included in the model. However, the coefficient remains highly significant. In contrast, the height of Guatemalan children is inversely associated with the proportion of households in the community with flush toilets, after controlling for individual, household and community characteristics. The same unexpected finding has been reported in previous analyses of the determinants of child anthropometry and survival in developing countries (Barrera 1990; Sastry 1996). Reverse causation (e.g. the choice of parents with shorter children to install a flush toilet in the household) and measurement errors have been suggested as possible explanations. The presence of a public dumpsite for garbage disposal in the community is associated with significantly better child growth patterns.

Our measures of community modernization are (jointly) significantly associated with height-forage. However, the effect of the proportion of women in the community who are literate is not significant in Models 6 and 7. The robustness of the effect of the proportion of households with a television underscores the existence of a diffusion process. Better access to the media is likely to influence norms, attitudes and behaviors regarding child care in the community. Note, however, that a higher percentage of households with a television may also reflect a higher socioeconomic status of the community not captured by the other community indicators included in the models.

Community-level economic variables do not significantly affect child anthropometry, with the exception of the size of the population in the community, which is negatively associated with growth outcomes in Models 4, 6 and 7. Apparently, a 'crowding' phenomenon occurs in rural Guatemala: for a given set of community characteristics, as more people have access to limited local infrastructure and services, children's health and nutritional outcomes appear to worsen. The association between the distance to the nearest market and the opportunity of regular employment in agricultural activities (measured by the presence of local farms and plantations within 20 kilometers of the community) becomes insignificant when individual and household covariates are also included in the analysis (Models 6 and 7). None of the coefficients for the prices of rice, beans, corn, sugar and salt is statistically significant.

Altitude is strongly and inversely associated with child height. Although the differentials in anthropometric outcomes are halved when socioeconomic characteristics of the households and the communities are controlled for, they remain substantial and highly significant. This finding is consistent with previous results (Pebley and Goldman 1995). Altitudes in Guatemala are too low to reflect the biological consequences of hypoxia and oxygen scarcity. Although the variables included in our analysis provide comprehensive controls for both household and community characteristics, including the 
remoteness of the community and the presence of labor opportunities in agriculture, they may not fully capture the poorer living conditions found at higher altitudes, including disadvantaged agricultural conditions and socioeconomic isolation.

Finally, the effects of health care facilities are jointly significant $(\mathrm{P}$-value $<0.01$ ). In particular, it is the availability of government health facilities, which provide services at a nominal fee, that is associated with better growth patterns. A unidirectional interpretation of the effect of government health care facilities on children's health and nutritional status relies on the assumption that the government program allocation is exogenous to child health. The presence of private health care facilities in the community is not significantly associated with children's attained height-for-age.

The coefficient associated with the number of doctors within 20 kilometers from the community is statistically significant. This result is consistent with previous research in Ghana indicating that children tend to be taller in communities with more doctors (Lavy et al. 1996). Two possible explanations are plausible. First, more doctors may provide better services as a result of better equipment and infrastructure or some other quality not reflected in the various characteristics included in the study. Second, private doctors may tend to locate in wealthier and better off communities where people can afford their services more easily. Unfortunately, we are not aware at this time of any studies on the placement of private health care providers in Guatemala.

Since the inclusion of endogenous variables biases the estimates of the effects of all the covariates with which they are correlated, we re-fitted Models 4, 6 and 7 excluding the number of private doctors from the list of covariates. None of the parameter estimates changed substantively (results not shown).

\subsection{Random Coefficients and Intra-Cluster Correlation}

Table 6 reports the estimates of the community, family and individual random effects as well as estimates of intra-cluster correlations associated with each model. Larger variances of the community and family random terms imply greater heterogeneity in anthropometric outcomes across groups and greater correlation among observations belonging to the same group. Because all children of the same mother live in the same community, intra-family correlations must be at least as large as intra-community correlations. Both correlations are constrained to lie between zero and one.

The bottom of Table 6 shows how the residual variance is distributed across communities, families and individual children. Estimates from the null model, which contains no observed covariates, indicate that the variation in height-for-age has substantial group-level components. The total variance is 
$1.721,{ }^{24}$ of which $42.8 \%$ is attributed to family- and community-level variation in anthropometric scores.

It is worth observing that the variation at the individual level is more than twice as great as the variations at the family and community level. Part of the individual variation is likely to be due to measurement errors originating from two possible sources: (1) errors in measurement of children's height and (2) misreporting of children's age. Intra-community correlation and intra-family correlation are both substantial, 0.21 and 0.43 respectively. Since age and sex are the only individual-level variables, we expect that the overall individual-level variation would be accounted for only slightly in reduced-form regressions. We limit the discussion below to changes in the community and family random effects across model specifications.

Estimates of the family random effect indicate that family heterogeneity is accounted for only partially by the observed covariates in our models. Only $44.1 \%{ }^{25}$ of the overall variation in child heightfor-age between families within communities is accounted for by the covariates in Model 6 .

Consequently, the intra-family correlation remains as large as 0.195 , suggesting that the height outcomes of two children belonging to the same family are more homogeneous that those of two children chosen at random, even after adjusting for other: observed covariates.

Results from Models 3 and 4 reveal that the community random effect is reduced considerably when either household or community characteristics are included as covariates $(67.1 \%$ and $89.0 \%$ of the initial community-level variation is accounted for respectively). The model with all exogenous covariates (Model 6) explains $93.2 \%{ }^{26}$ of the overall community-level variation. However, the community random effect is still highly significant. ${ }^{27}$ The intra-community correlation is reduced to a modest 0.021 in Model 6 , indicating that the clustering of height outcomes of children within communities is almost completely explained by the observed covariates.

Figure 3 conveys the same information by displaying the box-plots of the community-level residuals corresponding to the different models. Note again how the community-level variation, represented by the height of the boxes, is greatly reduced when either household covariates or community covariates or both are included in the regression models. Children living in communities lying above and below the horizontal line are, on average, shorter and taller respectively than predicted by the model. It is

\footnotetext{
${ }^{24} 0.365+0.372+0.984$

${ }^{25}(0.372-0.208) / 0.372$

${ }^{26}(0.365-0.025) / 0.365$

${ }^{27}$ Since variance estimates do not have a normal distribution, in order to test for the significance of both family and community random effects it is generally preferable to carry out a likelihood ratio test by estimating the deviance for the current model and the model omitting the random effects (see McCullagh and Nelder 1989). The test must, however, be modified to allow for the fact that the estimates are constrained to be nonnegative (Self and Liang 1987). The critical value for a chi-square test on one degree of freedom at the five percent level becomes 2.706 .
} 
possible to identify communities that are highly atypical. Figure 3 also shows the identification code for the two communities lying at the extreme of the distribution of Model 6 community-level residuals. These can be selected for further intensive qualitative examination, thus forming a link between the quantitatively-based multilevel analysis and a more qualitatively-based investigation. ${ }^{28}$

\subsection{Factors Accounting for Community-Level Variation}

We now look at the role of each factor in accounting for the variation in height-for-age $z$-scores across the 60 surveyed communities. To do so we proceed in two steps. First, we examine how the variance of the community random effect is reduced when we add each covariate alone to a reference model with only age and sex. Second, we look at how the variance is increased when we remove each covariate in turn from the full model.

Table 7 displays the parameter estimates. Altitude accounts for the largest proportion of the initial community-level variation. This finding holds both when we include altitude in the model with only age and sex $\left(\sigma_{c}^{2}\right.$ is reduced by $\left.42 \%\right)$ and when we omit it from the full model $\left(\sigma_{c}^{2}\right.$ is increased by $\left.64 \%\right)$. The high percentage increase in community-level variation resulting from removing altitude from the full model gives further credence to the idea that the observed covariates fail to capture in full the poorer living conditions that affect the growth of children living in communities at higher altitudes. Mother's height is the second most important covariate. Ethnicity and the presence of farms or plantations within

${ }^{28}$ We first examined the household characteristics in the two 'outlier' communities (i.e. the communities with the largest and smallest community-level residuals). Households in the community with the worst growth outcomes as compared to the model's predictions (identification code 21_2 7) are, on average, better off than households in the community with the best growth outcomes (identification code 8 -6_1). In the former community, the average proportion of indigenous people is 0.02 , the average height of mothers is 144.5 centimeters, the average level of mothers' education is 1.1 years, the average level of husbands' education is 1.9 years, and the average per capita household expenditure is 22.8 quetzals. In the latter community, all mothers are indigenous, the average height of mothers is 142.7 centimeters, the average level of mothers' education is 0.6 years, the average level of husbands' education is 0.7 years, and the average per capita household expenditure is 22.9 quetzals. However, the average zscore is -3.2 for children in the former community and -2.8 for children in the latter community.

We then compared the information collected by the EGSF community questionnaire in the two communities to investigate the reasons for their deviation from the predicted outcomes. These two communities are very similar in terms of the infrastructure and services that they provide to their residents. They do, however, differ with respect to migration patterns. Specifically, the key informants report that men living in community $21 \_2 \_7$ commonly migrate outside the community to work in plantations and farms. Conversely, men in the community _8_6_1 seem to remain, and work, in the community. Three factors help explain why children who depend on fathers' migration to work on plantations may be disadvantaged: (1) these children are generally of poorer families that have less land; (2) they often have long periods without income because their fathers are not able to start earning and sending money home immediately after they leave; and (3) they may receive little financial help, if any, because some of their fathers may spend their earnings in other activities. Although this argument remains speculative, we also postulate that children in community $21 \_2 \_7$ suffer disproportionately from the absence of their fathers, as fathers' education is a key factor in their children's growth process in rural Guatemala. On average, the fathers in this community have more than twice as many years of education as the fathers in community_8_6_1 (1.9 years and 0.7 years respectively). As a result of their absence, however, they may not always be able to fully contribute to their children's health and nutritional needs. 
20 kilometers of the community also have a substantial effect in the null model but not in the full model, suggesting that much of their effect is accounted for by the other covariates that appear in the full model.

\subsection{Intra-Family Correlation}

We have shown that, when no observed covariates are included in the model, the height-for-age outcomes of children living in the same family are more similar to each other than those of children chosen at random. We now investigate the specific covariates that link siblings' height-for-age outcomes. To look at this issue we follow the same two-step procedure that we used in the previous section. Since children who live in the same family also live in the same community, we focus on the intra-family correlation coefficient $\rho_{\mathrm{f}}$, which depends on both the community and family random effects.

Intra-family correlation declines from 0.338 to 0.195 when all exogenous covariates are included in the full model (see Table 8). The greater homogeneity of growth patterns observed among siblings is for the most part accounted for by those shared family background characteristics captured by mother's height, which may have affected uterine growth, lactation performance, exposure and susceptibility to infectious diseases, and perhaps child care. Specifically, the intra-family correlation is reduced by $24.9 \%$ when mother's height is included in the null model and is increased by $35.4 \%$ when it is excluded from the full model. Although parental education and household expenditure do have an effect on intra-family correlation, they are not nearly as important as mother's height. Note how ethnicity is associated with the smallest percentage changes, a finding that suggests a modest effect of ethnicity in accounting for the observed homogeneity of height-for-age outcomes among siblings.

\section{A CLOSER LOOK AT THE EFFECTS OF EDUCATION, INCOME AND ETHNICITY}

\subsection{Random-Coefficients Models}

We would like to test whether or not the effects of mother's education, husband's education, and household income are fixed across communities. To do so, we fit three random-coefficients models, which allow the effects of mother's education, husband's education and household per capita expenditure to vary randomly one at a time across communities. This involves introducing two additional random parameters at the community level in addition to the random intercept (the only random parameter in variance-components models): (1) a random slope representing the variation of the coefficient of education or income across the 60 communities, and (2) the covariance between the random slope and the random intercept.

Twice the difference of the log-likelihoods of the variance-components model and the randomcoefficients model is distributed as a chi-square statistic with two degrees of freedom and can be used to test the hypothesis regarding the randomness of the effects of each of the three variables of interest 
(mother's education, husband's education and household per capita expenditure). Table 9 reports the values of the resulting test statistics. In each one of the three cases the test fails to reject the null hypothesis that the effect is fixed across communities. The chi-square statistic for husband's education is the largest $(\mathrm{P}$-value $<0.10)$, suggesting some variation of the effect of husband's education on children's attained height from community to community. With respect to husband's education, in order to obtain a test based on fewer degrees of freedom, we also fitted a random-coefficients model in which the covariance between the random slope and the random intercept was constrained to be zero. ${ }^{29}$ The corresponding chi-square statistic with one degree of freedom (0.25), however, is still insignificant (Pvalue $=0.617$.

\subsection{Cross-Level Interactions between Mother's Education, Husband's Education, Expenditure Per}

\section{Capita and Community Services}

Table 10 shows the impact of interactions between parental education and household per capita expenditure and community services on child growth. The first, second and third models include interaction terms between all community characteristics (except for altitude) and mother's education, husband's education, and expenditure per capita respectively. The interactions between community services and either maternal education or per capita expenditure are not jointly significant. ${ }^{30}$ Moreover, none of the interactions is individually significant at the $5 \%$ confidence level. Apparently, the benefits of improved community services on child height are independent of maternal education and household resource availability or, rephrased, the effects of maternal education and household resource availability do not depend on the community environment.

The interaction terms between husband's education and community services are jointly significant, suggesting that the effect of husband's education varies across communities. ${ }^{31} \mathrm{We}$ limit the discussion to the two significant interactions between husband's education and community services. The presence of government health facilities is more beneficial for children of fathers with more education, suggesting that father's education acts as a complement to publicly provided health services. Similarly, the relationship between father's education and the number of doctors in the neighborhood of the community is complementary. This result suggest that parents need some knowledge and skill to take advantage of existing medical facilities. Apparently, in order to be beneficial for children's health and

\footnotetext{
${ }^{29}$ We did not perform the equivalent test for maternal education and household per capita expenditure because the effects of these variables showed very little variation across communities in the likelihood-ratio tests based on two degrees of freedom.

${ }^{30}$ The chi-square statistics on 17 degrees of freedom are 23.5 and 17.6 for maternal education and expenditure per capita respectively. The associated P-values are 0.133 and 0.435 .

${ }^{31}$ The chi-square statistic on 17 degrees of freedom is 49.7 . The associated P-value is less than 0.001 .
} 
nutritional status, both sets of health care facilities require knowledge, skills, attitudes and confidence that are provided to fathers at school through either formal education or both impersonal and interpersonal contacts.

\subsection{Interactions with Ethnicity}

In order to estimate parsimoniously how ethnic differentials in child growth are affected by household and community characteristics, we used a mixture of forward and backward model selection. First, we added to the reduced-form model the interaction terms between ethnicity (represented by a dummy variable that takes the value one if the mother of the child is indigenous) and selected household and community characteristics one at a time (Step 1). ${ }^{32}$ Then, we fitted a model including all interaction terms that were individually statistically significant in Step 1 (Step 2). Finally, we ran likelihood ratio tests on combinations of those interaction terms that became insignificant in Step 2 (Step 3). The results are shown in Table 11.

Note that none of the interaction terms with the variable denoting "Indigenous/Speaks Spanish" is significant. In Section 7.2 we noticed how differentials in growth between children of ladino mothers and children of indigenous mothers who speak Spanish became small and not significant when we controlled for all individual, household and community characteristics. We can now add that the magnitude of this differential does not depend on other characteristics of the household and the community.

On the other hand, some of the interaction terms with the variable "Indigenous/Does not Speak Spanish" are highly significant. Note also that all of these interaction terms have a negative sign, which suggests that the height differentials with children of ladino mothers grow even larger if the household or the community possesses the attribute under study. In particular, ethnic differentials in height-for-age increase with the level of both mother's and husband's education, suggesting that parents' education is more beneficial to children's health and nutrition when it is coupled with the mother's capacity to speak Spanish. Similarly, ethnic differentials are larger in communities that provide government health care facilities and have more private doctors in their neighborhood. This result is consistent with previous findings on the access to formal health services in Guatemala: as mentioned in Section 6.1, indigenous people who do not speak Spanish are more likely to have limited access to modern medical facilities then Spanish speakers and to experience more discrimination at the facilities that they attend.

\footnotetext{
${ }^{32}$ Household characteristics include mother's education, husband's education and expenditure per capita. Community characteristics include public health infrastructure, altitude and health care facilities and providers.
} 


\section{CONCLUSIONS}

Modeling children's height attainment in developing countries is a complex process that requires a conceptual and analytical framework, appropriate statistical tools, and a comprehensive data set. In this research, we used both the economic model of the family to guide the selection of the covariates and the interpretation of the parameter estimates of our models. We also fitted multilevel models to hierarchically clustered data in order to control for both family and community heterogeneity. Finally, a comprehensive data set provided the necessary information to model the impact of the multiple forces that affect children's growth differentials in such a diverse socioeconomic, cultural, ethnic and environmental context as rural Guatemala.

Our results confirm findings from previous research suggesting that poor child growth outcomes in Guatemala are the consequence of widespread poverty. In particular, we note that the large ethnic differentials in attained height between children of indigenous and children of ladino mothers are greatly reduced when we control for household and community characteristics. Moreover, ethnic differentials are no longer significant if the indigenous mother can speak Spanish. Children of educated parents experience

significantly better growth outcomes: education differentials, although reduced substantially, remain large and significant when we control for all exogenous household and community covariates.

The results also reveal that the family background characteristics captured by mothers' height are highly correlated with children's height-for-age, a finding that underscores the existence of a vicious cycle of poor nutrition that perpetuates itself across generations. In 1985, 500 million women of reproductive age in developing countries were estimated to be stunted as a result of protein-energy malnutrition during childhood (Leslie 1991). Stunted women suffer higher risks of mortality during childbirth and of poor birth outcomes such as low birthweight and high infant mortality (Habicht et al. 1973, Martorell and Ho 1984). On the basis of this relationship, growth impairment in children can be seen as only one stage of the intergenerational process that affects the well-being of a population. Support is needed for good nutrition at all stages - infancy, childhood, adolescence and adulthood - and especially for girls and women. From a development perspective, our results confirm that children's chronic malnutrition is likely to be influenced by general changes at the family-level, such as improvements in household income and parents' education.

Community characteristics, such as public health infrastructure and health care facilities, are also important determinants of children's height-for-age outcomes. In particular, we found that Guatemalan children in rural areas would benefit greatly from improvements of the community piped water connections and garbage disposal facilities. We postulated that the robustness of the effect of the proportion of households in the community with a television underscores the existence of a diffusion process of norms, attitudes and behaviors related to child health care. We found that the availability of 
government health care facilities, which provide medical services at a nominal fee, is significantly associated with better child health and nutrition outcomes, as is a higher number of doctors within 20 kilometers of the community. Finally, we observed that altitude differentials in anthropometric outcomes remain large and significant when we control for all exogenous covariates. Since altitudes in Guatemala are too low to produce hypoxia effects on growth, we hypothesized that this relationship reflects the poorer living conditions found at higher altitudes.

Random-coefficients models and variance-components models with cross-level interactions suggest that the effects of maternal education and expenditure per capita do not depend on the community environment, but that the effect of husband's education varies across communities. In particular, we found that both the presence of government health care facilities in the community and the number of private doctors in its neighborhood act as a complement to husband's education. This result has important distributional consequences since it indicates that children of more educated fathers would benefit disproportionately from a public policy directed to augmenting the provision of such medical services.

We also found that ethnic differentials in height-for-age outcomes between children of ladino mothers and children of indigenous mothers who do not speak Spanish are larger among children of more educated parents and among children living in communities with better health care facilities. Again, if the equity consequences of development policies are important, policy makers need to address the fact that the poorest children (that is the children of indigenous mothers who do not speak Spanish) are likely to benefit the least from the provision of both educational and medical infrastructure.

The results reveal that there is great variability in children's height-for-age outcomes across the 60 surveyed communities: the prevalence of stunting among children ranges from $20 \%$ to $88 \%$. Two important findings emerge from our analysis of the community-level random effects: (1) more than $90 \%$ of the overall community-level variation is explained by the exogenous household and community variables; and (2) altitude accounts for the largest proportion of the overall variation. Our models, however, fail to explain most of the initial intra-family correlation of height-for-age z-scores, which remains substantial even after controlling for observed individual, household and community covariates. The greater homogeneity of growth patterns among siblings is for the most part accounted for by those shared family genetic and background characteristics captured by mother's height. 


\section{REFERENCES}

ANTHRO. Software for Calculating Pediatric Anthropometry. Version 1.01. December 1990. U.S. Department of Health and Human Services, Atlanta, GA, and Nutritional Unit, World Health Organization, Geneva.

Barrera, A. 1990. The Role of Maternal Schooling and its Interaction with Public Health Programs in Child Health Production. Journal of Development Economics 32:69-91.

Becker, G. 1981. A Treatise on the Family. Cambridge: Harvard University Press.

Behrman, J.R. and A.B. Deolalikar. 1988. Health and Nutrition. Chapter 14 in Handbook of Development Economics, Volume I, eds. H. Chenery and T.N. Srinivasan. Amsterdam: Elsever Science Publishers.

Bilsborrow R.E. and D.K. Guilkey. 1987. Community and Institutional Influence on Fertility: Analytical Issues. Population and Labour Policies Programme Working Paper No. 157.

Bogin , B. and R.B. MacVean. 1982. Ethnic and Secular Influences on the Size and Maturity of Seven Year Old Children in Guatemala City. American Journal of Physical Anthropology 9:393-398.

Bogin , B. and R.B. MacVean. 1983. The Relationship of Socioeconomic Status and Sex to Body Size, Skeletal Maturation, and Cognitive Status of Guatemala City Schoolchildren. Child Development 54:115-128.

Burkhalter, B.R., R.I. Miller, L. Silva, and E. Burleigh. 1995. Variations in Estimates of Guatemalan Infant Mortality, Vaccination Coverage, and ORS Use Reported by Different Sources. Bulletin of PAHO 29(1):1-24.

Caldwell, J.C. 1979. Education as a Factor for Mortality Decline: An Examination of Nigerian Data. Population Studies 33:395-413.

Casterline, J.B., E.C. Cooksey and A.F. Ismail. 1989. Household Income and Child Survival in Egypt. Demography 26(1):15-34.

Cebu Study Team. 1992. A Child Health Production Function Estimated from Longitudinal Data. Journal of Development Economics 38(2):323-351.

Cebu Study Team. 1991. Underlying and Proximate Determinants of Child Health: The CEBU Longitudinal Health and Nutrition Study. American Journal of Epidemiology 133(2):185-201.

Cosminsky, S. 1987. Women and Health Care on a Guatemalan Plantation. Social Science and Medicine 25:1163-73.

DaVanzo, J., and P. Gertler. 1991. Household Production of Health: A Micro-Economic Perspective on Health Transitions. Pp. 85-101 in The Health Transition: Methods and Measures, eds. J. Cleland and A.G. Hill. Canberra: The Australian National University Press.

de Onis, M., C. Monteiro, J. Akre, and G. Glugstone. 1993. The Worldwide Magnitude of Protein-Energy Malnutrition: an Overview from the WHO Global Database on Child Growth. Bull. World Heallh Organ. 71,6:703-712.

Entwisle, B., J.B. Casterline and U.A.-A. Sayed. 1989. Villages as Contexts for Contraceptive Behavior in Rural Egypt. American Sociological Review 54, Dec: 1019-1034.

Foster, A. 1990. Rice Prices, Credit Markets and Child Growth in Rural Bangladesh. Mimeo. (University of Pennsylvania, Philadelphia, PA). 
Frankenberg, E. 1995. The Effects of Access to Health Care on Infant Mortality in Indonesia. Health Transition and Review 5:143-163.

Goldman N. and A.R. Pebley. 1994. Health Cards, Maternal Reports and the Measurement of Immunization Coverage: The Example of Guatemala. Social Science and Medicine 38(8):1075-1089.

Habicht, J.-P., C. Yarbrough, A. Lechtig, R.E. Klein. 1973. Relationship of Birth Weight, Maternal Nutrition and Infant Mortality. Nutr. Repr. Int. 7: 533-546.

Hausman, J.A. 1978. Specification Test in Econometrics. Econometrica 46:1251-71.

Johnston, F.E., M. Borden. and R.B. MacVean. 1973. Height, Weight and Their Growth Velocities in Guatemalan Private School Children of High Socioeconomic Class. Human.Biology 45:627-641.

Keller W. 1983. Choice of Indicators of Nutritional Status. In Evaluation of Nutrition Education in Third World Communities. Ed. B. Schurch. Nestle' Foundation Publication Series. Bern: Hans Huber Publishers.

Lavy V., J. Strauss, D. Thomas, and P. de Vreyer. 1996. Quality of Health Care, Survival and Health Outcomes in Ghana. Journal of Health Economics 15:333-357.

Leslie, J. 1991. Women's Nutrition: The Key to Improving Family Health in Developing Countries. Health Policy Plan 6:1-19.

Martorell, R. 1982. Nutrition and Health Status Indicators: Suggestions for Surveys of the Standard of Living in Developing Countries. LSMS Working Paper 13. The World Bank. Washington, DC.

Martorell, R, and J.-P. Habicht. 1986. Growth in Early Childhood in Developing Countries. Pp. 241-262 in Human Growth: A Comprehensive Treatise, eds. F. Falkner and J.M. Tanner, Volume 3. New York: Plenum Press.

Martorell, R. and T.J. Ho. 1984. Malnutrition, Morbidity and Mortality. Pp. 49-68 in Child Survival: Strategies for Research, eds. W.H. Mosley and L.C. Chen. Supplement to Population and Development Review 10.

McCullagh, P. and J.A. Nelder 1989. Generalized Linear Models. London: Chapman and Hall.

Mosley, W.H. and L. Chen .1984. An Analytical Framework for the Study of Child Survival in Developing Countries. Pp. 25-48 in Child Survival: Strategies for Research, eds. W.H. Mosley and L.C. Chen. Supplement to Population and Development Review 10.

Mueller, W. 1986. The Genetics of Size and Shape in Children and Adults. Pp. 241-262 in Human Growth: A Comprehensive Treatise, eds. F. Falkner and J.M. Tanner, Volume 3. New York: Plenum Press.

Pebley A.R., N. Goldman and G. Rodríguez. 1996. Prenatal and Delivery Care and Childhood Immunization in Guatemala: Do family and Community Matter? Demography 33(2):1-18.

Pebley, A.R. and N. Goldman. 1995. Social Inequality and Children's Growth in Guatemala. Health Transition Review 5:1-20.

Peterson, C., N. Goldman and A. Pebley. 1997. The 1995 Guatemalan Survey of Family Health (EGSF): Overview and Codebook. RAND, Santa Monica CA

Pitt, M., M.R. Rosenzweig and D.M. Gibbons. 1994. The Determinants and Consequences of the Placement of Government Programs in Indonesia. World Bank Economic Review 7:319-348.

Rao, D.H. and J.G. Sastry. 1977. Growth Pattern of Well-to-Do Indian Adolescents and Young Children. Indian J. Med. Res. 66:950-956. 
Rasbash, J., M. Yang, G. Woodhouse, and H. Goldstein. 1995. Mln: Command Reference Guide: London: Institute of Education.

Rosenzweig, M. And K. Wolpin. 1986. Evaluating the Effects of Optimally Distributed Public Programs: Child Health and Family Planning Interventions. American Economic Review 76:470-82.

Sastry, N. 1996. Community Characteristics, Individual and Household Attributes, and Child Survival in Brazil. Demography 33(2):211-229.

Schultz T.P. 1984. Studying the Impact of Household Economic Variables on Child Mortality. Pp. 215235 in Child Survival: Strategies for Research, eds. W.H. Mosley and L.C. Chen. Supplement to Population and Development Review 10.

Singh I., L. Squire and J. Strauss. 1986. Agricultural Household Models: Extensions, Applications and Policy. Baltimore: The Johns Hopkins University Press.

StataCorp. 1997. Stata Statistical Software. Release 5. College Station, TX: Stata Corporation.

Steele, D. 1993. Guatemala. Pp. 105-140 in Indigenous People and Poverty in Latin America: An Empirical Analysis, eds. G. Psacharopoulos and H. Patrinos. Washington DC: World Bank.

Thomas, D. and J. Strauss. 1992. Prices, Infrastructure, Household Characteristics and Child Height. Journal of Development Economics 39:301-331.

Tienda, M. 1991. Poor People and Poor Places: Deciphering Neighborhood Effects on Poverty Outcomes. Pp. 244-262 in Macro-Micro Linkages in Sociology, ed. J. Haber. Newbury Park, CA: Sage.

UNICEF. 1998. The State of the World's Children. Oxford University Press.

Waterlow, J.R., W. Buzina, W. Keller, J. Lane, M. Nichaman, and J. Tanner. 1977. The Presentation and Use of Height and Weight Data for Comparing the Nutritional Status of Groups of Children under the Age of 10 Years. Bulletin of the World Health Organization 55(4):489-498.

World Health Organization. 1983. Measuring Change in Nutritional Status. WHO, Geneva.

World Health Organization. 1979. Measurement of Nutritional Impact. WHO, Geneva.

WHO Working Group. 1986. Use and Interpretation of Anthropometric Indicators of Nutritional Status. Bulletin of the World Health Organization 64:924-941. 
FIGURE 1: AVERAGE $Z$ - SCORES FOR HEIGHT-FOR-AGE BY AGE AND SEX IN GUATEMALAN CHILDREN

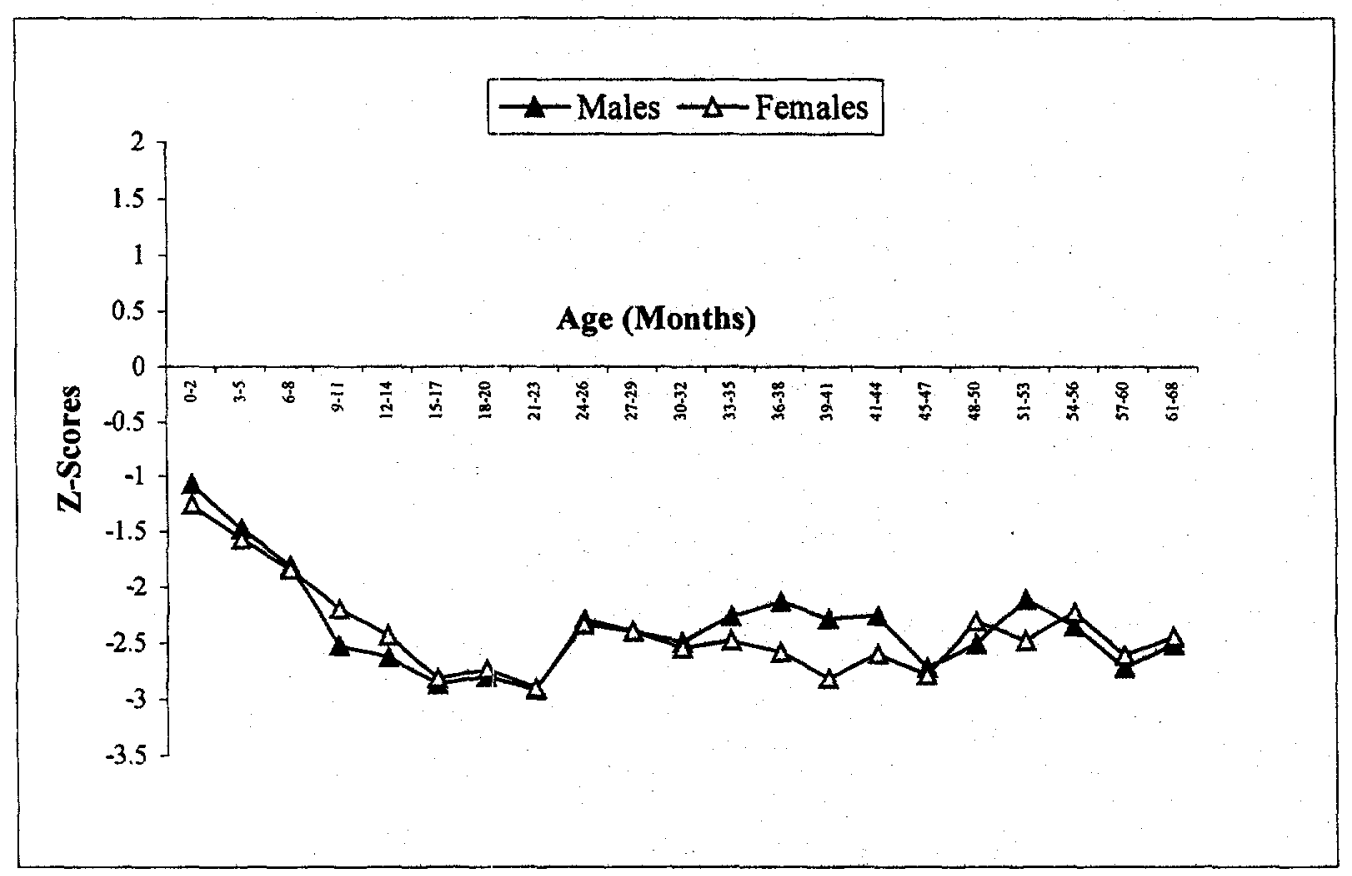


TABLE 1: MEAN Z-SCORES FOR HEIGHT-FOR-AGE, STANDARD DEVIATIONS AND PREVALENCE OF STUNTING BY ETHNICITY/LANGUAGE, PARENTAL EDUCATION AND HOUSEHOLD EXPENDITURE PER CAPITA

\begin{tabular}{lccc}
\hline & Mean & SD & \% Stunted \\
\hline Ethinity/language & & & \\
$\quad$ Ladino & -1.99 & 1.34 & 48.8 \\
$\quad$ Indigenous and Spanish & -2.27 & 1.19 & 60.1 \\
$\quad$ Indigenous and No Spanish & -2.87 & 1.19 & 77.0 \\
Mother's Education & & & \\
$\quad$ None & -2.64 & 1.29 & 69.0 \\
$\quad$ Primary & -2.28 & 1.21 & 59.1 \\
Secondary + & -1.17 & 1.45 & 26.5 \\
Husband's Education & & & \\
$\quad$ None & -2.62 & 1.26 & 70.5 \\
$\quad$ Primary & -2.34 & 1.25 & 60.3 \\
$\quad$ Secondary & -1.62 & 1.37 & 37.4 \\
$\quad$ Higher & -0.44 & 1.41 & 8.0 \\
Expenditure per Capita & & & \\
$\quad$ First Quartile & -2.67 & 1.21 & 72.7 \\
$\quad$ Second Quartile & -2.50 & 1.24 & 66.9 \\
$\quad$ Third Quartile & -2.32 & 1.26 & 59.0 \\
$\quad$ Fourth Quartile & -1.90 & 1.36 & 45.3 \\
\hline
\end{tabular}


TABLE 2: MEAN Z-SCORES FOR HEIGHT-FOR-AGE AND PREVALENCE OF STUNTING BY AGE GROUP AND DEPARTMENT

\begin{tabular}{|c|c|c|c|c|c|c|c|c|c|c|}
\hline \multirow[b]{2}{*}{$\begin{array}{c}\text { Age } \\
\text { group } \\
\text { (months) }\end{array}$} & \multicolumn{2}{|c|}{ All Departments } & \multicolumn{2}{|c|}{ Chimaltenango } & \multicolumn{2}{|c|}{ Totonicapán } & \multicolumn{2}{|c|}{ Suchitepéquez } & \multicolumn{2}{|c|}{ Jalapa } \\
\hline & $\begin{array}{l}\text { Mean Z- } \\
\text { Score }\end{array}$ & $\begin{array}{c}\% \\
\text { Stunted }\end{array}$ & $\begin{array}{c}\text { Mean Z- } \\
\text { Score }\end{array}$ & $\begin{array}{c}\% \\
\text { Stunted }\end{array}$ & $\begin{array}{c}\text { Mean Z- } \\
\text { Score }\end{array}$ & $\begin{array}{c}\% \\
\text { Stunted }\end{array}$ & $\begin{array}{c}\text { Mean Z- } \\
\text { Score }\end{array}$ & $\begin{array}{c}\% \\
\text { Stunted }\end{array}$ & $\begin{array}{c}\text { Mean Z- } \\
\text { Score }\end{array}$ & $\begin{array}{c}\% \\
\text { Stunted }\end{array}$ \\
\hline $0-2$ & -1.2 & 20 & -1.4 & 25 & -1.8 & 36 & -0.6 & 5 & -1.0 & 15 \\
\hline $3-5$ & -1.5 & 33 & -1.7 & 36 & -2.2 & 59 & -0.8 & 5 & -1.5 & 32 \\
\hline $6-8$ & -1.8 & 42 & -1.7 & 42 & -2.4 & 62 & -1.3 & 22 & -1.9 & 40 \\
\hline $9-11$ & -2.4 & 62 & -2.2 & 53 & -3.0 & 79 & -1.9 & 43 & -2.4 & 73 \\
\hline $12-14$ & -2.5 & 64 & -2.7 & 78 & -3.1 & 78 & -2.0 & 48 & -2.2 & 56 \\
\hline $15-17$ & -2.9 & 74 & -2.6 & 72 & -3.7 & 80 & -2.4 & 68 & -2.7 & 78 \\
\hline $18-20$ & -2.8 & 72 & -2.9 & 76 & -3.6 & 81 & -2.1 & 56 & -2.6 & 73 \\
\hline $21-23$ & -2.9 & 78 & -2.8 & 77 & -3.4 & 79 & -2.7 & 80 & -2.7 & 75 \\
\hline $24-26$ & -2.3 & 56 & -2.7 & 66 & -2.8 & 68 & -1.6 & 38 & -2.2 & 51 \\
\hline $27-29$ & -2.4 & 62 & -2.3 & 66 & -3.0 & 74 & -1.8 & 39 & -2.3 & 65 \\
\hline $30-32$ & -2.5 & 63 & -2.3 & 52 & -3.0 & 74 & -2.3 & 63 & -2.4 & 59 \\
\hline $33-35$ & -2.4 & 59 & -2.7 & 69 & -3.2 & 62 & -2.1 & 57 & -2.2 & 53 \\
\hline $36-38$ & -2.4 & 60 & -2.9 & 79 & -2.8 & 70 & -1.9 & 46 & -2.0 & 49 \\
\hline $39-41$ & -2.6 & 63 & -2.7 & 70 & -2.9 & 67 & -2.2 & 52 & -2.5 & 66 \\
\hline $42-44$ & -2.4 & 57 & -2.8 & 64 & -3.3 & 77 & -1.9 & 45 & -1.7 & 43 \\
\hline $45-47$ & -2.8 & 71 & -2.7 & 67 & -3.4 & 88 & -2.3 & 61 & -2.5 & 67 \\
\hline $48-50$ & -2.4 & 65 & -2.5 & 68 & -3.0 & 81 & -2.0 & 55 & -2.4 & 63 \\
\hline $51-53$ & -2.3 & 59 & -2.3 & 66 & -2.8 & 73 & -1.9 & 46 & -2.1 & 43 \\
\hline $54-56$ & -2.3 & 52 & -2.2 & 50 & -3.0 & 61 & -2.0 & 47 & -2.2 & 51 \\
\hline $57-60$ & -2.8 & 67 & -2.9 & 73 & -3.2 & 77 & -2.5 & 54 & -2.5 & 64 \\
\hline $61-68$ & -2.5 & 65 & -2.4 & 63 & -3.2 & 80 & -2.1 & 57 & -2.5 & 59 \\
\hline $0-68$ & -2.4 & 62 & -2.5 & 62 & -3.0 & 72 & -1.9 & 47 & -2.2 & 57 \\
\hline
\end{tabular}


TABLE 3: PREVALENCE ÓF STUNTING AND MEAN Z-SCORE FOR HEIGHT-FOR-AGE BY COMMUNITY WITHIN DEPARTMENT

\begin{tabular}{ccccccccc}
\hline & \multicolumn{2}{c}{ Chimaltenango } & \multicolumn{2}{c}{ Totonicapán } & \multicolumn{2}{c}{ Suchitepéquez } & \multicolumn{2}{c}{ Jalapa } \\
\hline community & Mean Z- & $\%$ & Mean Z- & $\%$ & Mean Z- & $\%$ & Mean Z- & $\%$ \\
& Score & Stunted & Score & Stunted & Score & Stunted & Score & Stunted \\
1 & -2.3 & 64 & -2.6 & 67 & -1.1 & 24 & -2.7 & 71 \\
2 & -2.7 & 72 & -2.8 & 74 & -1.8 & 42 & -2.7 & 70 \\
3 & -2.1 & 55 & -2.6 & 75 & -1.5 & 29 & -3.3 & 88 \\
4 & -2.0 & 38 & -2.7 & 67 & -2.1 & 45 & -3.2 & 82 \\
5 & -3.0 & 79 & -3.3 & 80 & -1.3 & 24 & -2.2 & 61 \\
6 & -3.3 & 79 & -3.0 & 72 & -2.0 & 59 & -1.7 & 39 \\
7 & -2.4 & 56 & -3.2 & 82 & -1.8 & 45 & -1.5 & 27 \\
8 & -2.9 & 75 & -2.9 & 69 & -1.9 & 43 & -1.6 & 40 \\
9 & -2.8 & 73 & -2.7 & 71 & -2.5 & 68 & -2.7 & 78 \\
10 & -2.4 & 70 & -3.1 & 77 & -2.1 & 60 & -1.6 & 35 \\
11 & -2.7 & 76 & -3.4 & 69 & -2.4 & 66 & -1.3 & 33 \\
12 & -2.4 & 68 & -3.1 & 69 & -2.4 & 53 & -2.3 & 51 \\
13 & -1.9 & 34 & -3.2 & 71 & -2.3 & 59 & -1.4 & 22 \\
14 & -2.1 & 47 & -3.5 & 73 & -1.7 & 35 & -2.0 & 55 \\
15 & -1.9 & 50 & -2.8 & 68 & -1.1 & 20 & -1.7 & 42 \\
All & -2.5 & $\mathbf{6 2}$ & $\mathbf{- 3 . 0}$ & $\mathbf{7 2}$ & -1.9 & $\mathbf{4 7}$ & $-\mathbf{2 . 2}$ & $\mathbf{5 7}$ \\
\hline
\end{tabular}


FIGURE 2: DISTRIBUTION OF AVERAGE Z-SCORES FOR HEIGHT-FOR-AGE ACROSS COMMUNITIES WITHIN DEPARTIMENTS

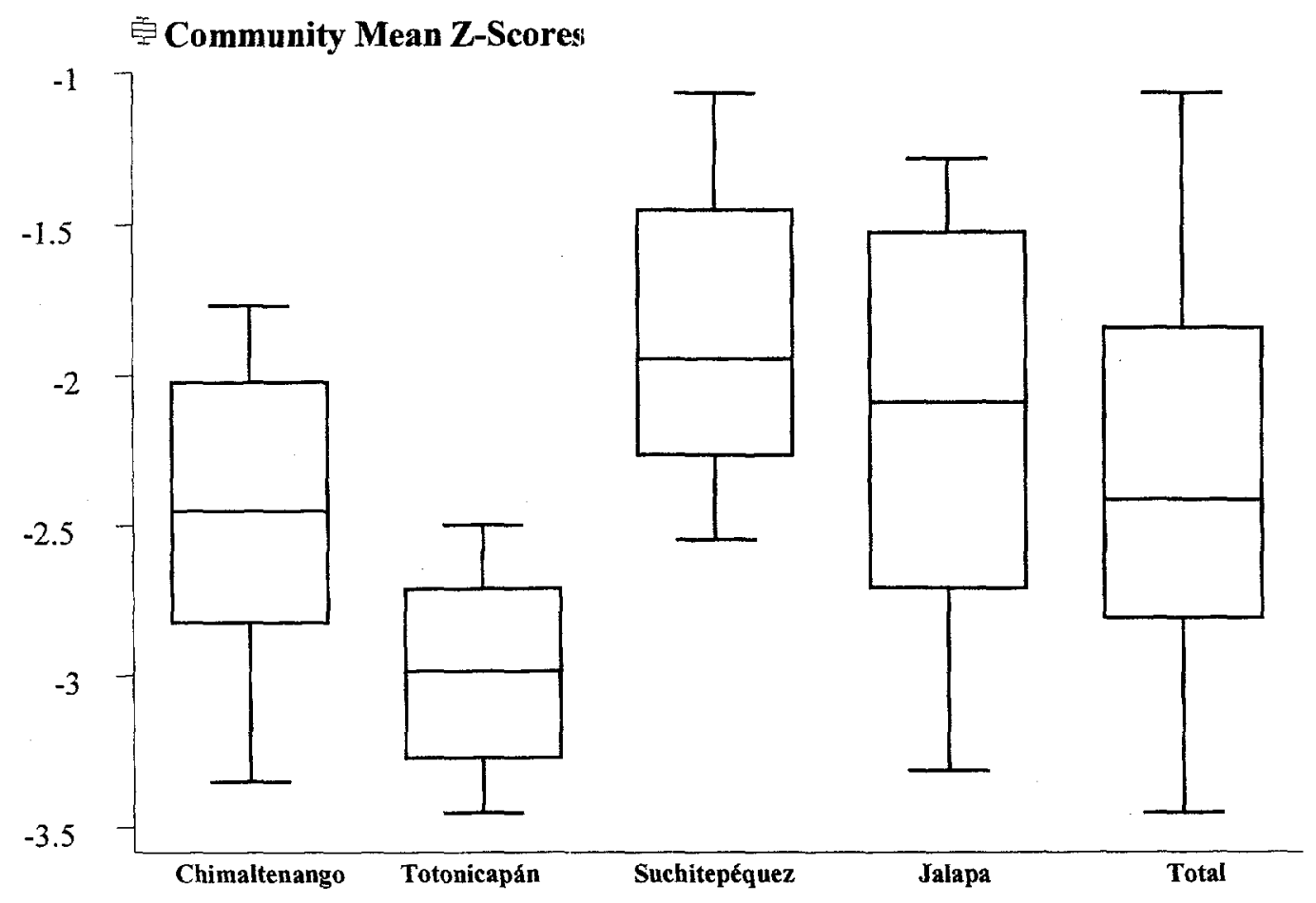


TABLE 4: SUMMARY STATISTICS FOR INDIVIDUAL, HOUSEHOLD, AND COMMUNITY COVARIATES (2963 OBSERVATIONS)

\begin{tabular}{|c|c|c|c|c|c|}
\hline & All & Chimaltenango & Totonicapán & Suchitepéquez & Jalapa \\
\hline Number of Children & 2963 & 727 & 784 & 853 & 862 \\
\hline \multicolumn{6}{|l|}{ Ht/A Z-Score } \\
\hline $\begin{array}{l}\text { Mean } \\
\text { (Standard deviation) }\end{array}$ & $\begin{array}{c}-2.4 \\
(1.3)\end{array}$ & $\begin{array}{l}-2.5 \\
(1.2)\end{array}$ & $\begin{array}{l}-3.0 \\
(1.2)\end{array}$ & $\begin{array}{l}-1.9 \\
(1.2)\end{array}$ & $\begin{array}{l}-2.2 \\
(1.3)\end{array}$ \\
\hline \multicolumn{6}{|l|}{ CHILD VARIABLES } \\
\hline \multicolumn{6}{|l|}{ Age (months) } \\
\hline $\begin{array}{l}\text { Mean } \\
\text { (Standard deviation) }\end{array}$ & $\begin{array}{c}45.9 \\
(16.1)\end{array}$ & $\begin{array}{c}46.7 \\
(15.8)\end{array}$ & $\begin{array}{c}45.1 \\
(16.1)\end{array}$ & $\begin{array}{c}46.2 \\
(16.1)\end{array}$ & $\begin{array}{c}45.5 \\
(16.3)\end{array}$ \\
\hline \multicolumn{6}{|l|}{ Sex } \\
\hline Males & $50.0 \%$ & $45.8 \%$ & $48.4 \%$ & $51.1 \%$ & $50.9 \%$ \\
\hline \multicolumn{6}{|l|}{ HOUSEHOLD VARIABLES } \\
\hline \multicolumn{6}{|l|}{ Ethnicity/Language } \\
\hline Ladino & $36.4 \%$ & $8.1 \%$ & $0.9 \%$ & $26.6 \%$ & $99.0 \%$ \\
\hline Indigenous \& Spanish & $34.2 \%$ & $53.2 \%$ & $21.4 \%$ & $61.1 \%$ & $1.0 \%$ \\
\hline Indigenous \& No Spanish & $29.4 \%$ & $38.7 \%$ & $77.7 \%$ & $12.3 \%$ & $0.0 \%$ \\
\hline \multicolumn{6}{|l|}{ Mother's Height (cms) } \\
\hline $\begin{array}{l}\text { Mean } \\
\text { (Standard deviation) }\end{array}$ & $\begin{array}{l}147.1 \\
(5.5)\end{array}$ & $\begin{array}{l}146.6 \\
(4.8)\end{array}$ & $\begin{array}{l}144.7 \\
(4.8)\end{array}$ & $\begin{array}{l}147.6 \\
(5.5)\end{array}$ & $\begin{array}{l}148.8 \\
(5.8)\end{array}$ \\
\hline \multicolumn{6}{|l|}{ Mother's Education (years) } \\
\hline $\begin{array}{l}\text { Mean } \\
\text { (Standard deviation) }\end{array}$ & $\begin{array}{c}2.3 \\
(2.7)\end{array}$ & $\begin{array}{c}3.0 \\
(2.8)\end{array}$ & $\begin{array}{c}1.3 \\
(1.8)\end{array}$ & $\begin{array}{c}2.4 \\
(3.0)\end{array}$ & $\begin{array}{c}2.3 \\
(2.8)\end{array}$ \\
\hline None & $37.5 \%$ & $19.6 \%$ & $49.5 \%$ & $42.1 \%$ & $38.0 \%$ \\
\hline Primary & $56.9 \%$ & $73.1 \%$ & $48.8 \%$ & $48.8 \%$ & $56.8 \%$ \\
\hline Secondary or higher & $5.6 \%$ & $7.3 \%$ & $0.7 \%$ & $8.4 \%$ & $5.2 \%$ \\
\hline \multicolumn{6}{|l|}{ Husband's Education (years) } \\
\hline $\begin{array}{l}\text { Mean } \\
\text { (Standard deviation) }\end{array}$ & $\begin{array}{c}3.2 \\
(3.1)\end{array}$ & $\begin{array}{c}4.5 \\
(3.3)\end{array}$ & $\begin{array}{c}2.5 \\
(2.5)\end{array}$ & $\begin{array}{c}3.2 \\
(3.4)\end{array}$ & $\begin{array}{c}2.6 \\
(2.8)\end{array}$ \\
\hline None & $27.3 \%$ & $12.8 \%$ & $31.4 \%$ & $29.5 \%$ & $34.3 \%$ \\
\hline Primary & $64.7 \%$ & $73.1 \%$ & $63.8 \%$ & $61.1 \%$ & $61.5 \%$ \\
\hline Secondary & $7.2 \%$ & $12.8 \%$ & $4.6 \%$ & $8.3 \%$ & $3.3 \%$ \\
\hline Post-secondary & $0.8 \%$ & $1.3 \%$ & $0.0 \%$ & $1.1 \%$ & $0.9 \%$ \\
\hline \multicolumn{6}{|l|}{$\begin{array}{l}\text { Household Expenditure Per } \\
\text { Capita (quetzals per month) }\end{array}$} \\
\hline $\begin{array}{l}\text { Mean } \\
\text { (Standard deviation) }\end{array}$ & $\begin{array}{c}22.3 \\
(14.1)\end{array}$ & $\begin{array}{c}20.1 \\
(12.0)\end{array}$ & $\begin{array}{c}20.1 \\
(12.0)\end{array}$ & $\begin{array}{c}23.8 \\
(13.7)\end{array}$ & $\begin{array}{c}24.4 \\
(17.0)\end{array}$ \\
\hline
\end{tabular}




\section{COMMUNITY VARIABLES}

Public Health Infrastructure

$\%$ hhs with tap water inside ${ }^{a}$

Mean

(Standard deviation)

$\%$ hhs with toilet inside ${ }^{\mathrm{a}}$

Mean

(Standard deviation)

Public dumpsite

Modernization

$\%$ hhs with TV

Mean

(Standard deviation)

$\%$ literate women ${ }^{\mathrm{a}}$

Mean

(Standard deviation)

\section{Economic Structure}

Paved road

Commercial farms/Plantations

Distance to nearest market $(\mathrm{kms})$

Mean

(Standard deviation)

Total population

Mean

(Standard deviation)

Bank/Rural cooperative

Food Prices (quetzals/ounce)

Rice

Mean

(Standard deviation)

Beans

Mean

Corn

(Standard deviation)

Mean

(Standard deviation)

Sugar

Mean

(Standard deviation)

Salt

Mean

(Standard deviation) $\begin{array}{ccccc}0.04 & 0.02 & 0.001 & 0.15 & 0.01 \\ (0.11) & (0.03) & (0.01) & (0.19) & (0.02)\end{array}$

$\begin{array}{lllll}0.09 & 0.09 & 0.01 & 0.16 & 0.08\end{array}$

$\begin{array}{lllll}(0.16) & (0.12) & (0.02) & (0.23) & (0.15)\end{array}$

$\begin{array}{lllll}8.3 \% & 11.5 \% & 6.1 \% & 10.5 \% & 5.1 \%\end{array}$

$\begin{array}{ccccc}0.33 & 0.45 & 0.25 & 0.33 & 0.27 \\ (0.24) & (0.20) & (0.18) & (0.27) & (0.26) \\ & & & & \\ 0.73 & 0.89 & 0.59 & 0.72 & 0.76 \\ (0.19) & (0.08) & (0.17) & (0.18) & (0.19)\end{array}$

$\begin{array}{lllll}6.6 \% & 0.0 \% & 13.9 \% & 13.1 \% & 0.0 \%\end{array}$

$\begin{array}{lllll}59.3 \% & 49.8 \% & 0.0 \% & 92.3 \% & 81.8 \%\end{array}$

$\begin{array}{ccccc}7.8 & 6.6 & 3.1 & 8.5 & 12.9 \\ (9.6) & (4.5) & (2.9) & (12.3) & (12.4) \\ & & & & \\ 2,587 & 2,708 & 3,008 & 2,587 & 2,046 \\ (2,120) & (2,563) & (1,219) & (2,293) & (2,260) \\ 51.6 \% & 68.8 \% & 24.4 \% & 32.1 \% & 77.9 \%\end{array}$

$\begin{array}{ccccc}1.8 & 1.9 & 1.7 & 1.7 & 1.8 \\ (0.2) & (0.2) & (0.2) & (0.2) & (0.2)\end{array}$

$\begin{array}{lllll}1.9 & 1.8 & 2.2 & 2.1 & 1.4\end{array}$

$\begin{array}{llll}(0.5) & (0.5) & (0.4) & (0.4)\end{array}$

$\begin{array}{lllll}0.5 & 0.4 & 0.6 & 0.6 & 0.5\end{array}$

$\begin{array}{llll}(0.1) & (0.1) & (0.1) & (0.1)\end{array}$

$\begin{array}{lllll}1.4 & 1.4 & 1.4 & 1.4 & 1.4\end{array}$

$\begin{array}{lllll}(0.07) & (0.06) & (0.03) & (0.09) & (0.05)\end{array}$

$\begin{array}{ccccc}0.4 & 0.4 & 0.3 & 0.4 & 0.4 \\ (0.09) & (0.08) & (0.08) & (0.09) & (0.07)\end{array}$


(Table 4 continued form previous page)

All

Chimaltenango Totonicapán Suchitepéquez

Jalapa

Ecological Characteristics

Altitude (meters)

Mean

(Standard deviation)

1,570

$2,086.7$

$2,593.3$

410.0

$1,193.3$

(885.3)

(294.3)

(303.5)

(178.5)

(300.5)

Health Care Services

Private $\mathrm{HCF}^{\mathfrak{c}}$ in the community

Government $\mathrm{HCF}^{\mathrm{d}}$ in community

Number of doctors within $20 \mathrm{kms}$

Mean

$50.5 \%$

$47.6 \%$

$79.4 \%$

$49.1 \%$

$31.4 \%$

$37.7 \%$

$49.5 \%$

$29.0 \%$

$48.4 \%$

$22.8 \%$

(Standard deviation)

1.52

1.00

0.73

1.53

2.80

$(1.75)$

(1.13)

(0.96)

(1.36)

(2.48)

${ }^{a}$ From individual questionnaire.

${ }^{b}$ Altitude of the municipality capital.

${ }^{c}$ Hospital, clinic and pharmacy.

${ }^{\mathrm{d}}$ Health center, health post and IGSS clinic. 
TABLE 5: RESULTS OF MULTILEVEL LINEAR REGRESSION MODELS (MAIN EFFECTS)

\begin{tabular}{|c|c|c|c|c|c|c|c|}
\hline & Model $1^{2}$ & Model 2 & Model 3 & Model 4 & Model 5 & Model 6 & Model 7 \\
\hline Constant & $\begin{array}{l}-2.333^{\star * *} \\
(0.081)\end{array}$ & $\begin{array}{l}-1.534^{* * *} \\
(0.120)\end{array}$ & $\begin{array}{l}-2.432 * * * \\
(0.095)\end{array}$ & $\begin{array}{c}-3.881 * * * \\
(1.284)\end{array}$ & $\begin{array}{l}-1.620^{* * * *} \\
(0.128)\end{array}$ & $\begin{array}{c}-2.317^{* *} \\
(1.102)\end{array}$ & $\begin{array}{c}-2.406^{* *} \\
(1.120)\end{array}$ \\
\hline CHILD VARIABLES & & \#\#\# & & & $\# \#$ & \#\# & \#\# \\
\hline \multicolumn{8}{|l|}{ Age } \\
\hline Age (months) & $\begin{array}{c}-0.017^{* * *} \\
(0.002)\end{array}$ & $\begin{array}{c}-0.017^{* * *} \\
(0.002)\end{array}$ & & & $\begin{array}{c}-0.016^{* * * *} \\
(0.002)\end{array}$ & $\begin{array}{c}-0.016^{* * *} \\
(0.002)\end{array}$ & $\begin{array}{c}-0.015 * * * \\
(0.002)\end{array}$ \\
\hline $\begin{array}{l}\text { Age * dummy } \\
(\text { dummy }=1 \text { if age }<24)\end{array}$ & $\begin{array}{c}-0.028 * * * \\
(0.006)\end{array}$ & $\begin{array}{c}-0.028 * * * \\
(0.006)\end{array}$ & & & $\begin{array}{c}-0.030^{* * * *} \\
(0.006)\end{array}$ & $\begin{array}{c}-0.031 * * * \\
(0.005)\end{array}$ & $\begin{array}{c}-0.030^{* * *} \\
(0.005)\end{array}$ \\
\hline \multicolumn{8}{|l|}{ Sex } \\
\hline $\begin{array}{l}\text { (Female) } \\
\text { Male }\end{array}$ & $\begin{array}{c}-- \\
-0.013 \\
(0.049)\end{array}$ & $\begin{array}{c}-\overline{-0} \\
-0.008 \\
(0.048)\end{array}$ & & & $\begin{array}{c}- \\
-0.001 \\
(0.044)\end{array}$ & $\begin{array}{c}-\overline{-} \\
0.005 \\
(0.044)\end{array}$ & $\begin{array}{c}-\overline{0} \\
0.014 \\
(0.044)\end{array}$ \\
\hline HOUSEHOLD VARIABLES & & & \#\# & & \#\# & $\#$ & $\#$ \\
\hline \multicolumn{8}{|l|}{ Ethnicity } \\
\hline (Ladino) & $-\cdots$ & & - & & -- & - & -- \\
\hline Indigenous \& Spanish & $\begin{array}{c}-0.547^{* * * *} \\
(0.091)\end{array}$ & & $\begin{array}{c}-0.250^{* * *} \\
(0.081)\end{array}$ & & $\begin{array}{c}-0.245^{* * *} \\
(0.080)\end{array}$ & $\begin{array}{l}-0.128 \\
(0.080)\end{array}$ & $\begin{array}{l}-0.130 \\
(0.080)\end{array}$ \\
\hline Indigenous \& No Spanish & $\begin{array}{c}-0.832 * * * k \\
(0.105)\end{array}$ & & $\begin{array}{c}-0.440 * * * \\
(0.093)\end{array}$ & & $\begin{array}{c}-0.465 * * * \\
(0.092)\end{array}$ & $\begin{array}{l}-0.229 * * \\
(0.098)\end{array}$ & $\begin{array}{c}-0.228 * * \\
(0.099)\end{array}$ \\
\hline \multicolumn{8}{|l|}{ Mother's Height ${ }^{b}$} \\
\hline Cms. & $\begin{array}{c}0.068 * * * \\
(0.005)\end{array}$ & & $\begin{array}{c}0.057^{* * *} \\
(0.005)\end{array}$ & & $\begin{array}{c}0.058 * * * \\
(0.005)\end{array}$ & $\begin{array}{c}0.056 * * * \\
(0.005)\end{array}$ & $\begin{array}{c}0.055^{* * *} \\
(0.005)\end{array}$ \\
\hline \multicolumn{8}{|l|}{ Mother's Education } \\
\hline Years & $\begin{array}{c}0.104^{* * * * 1 *} \\
(0.01)\end{array}$ & & $\begin{array}{c}0.048^{* * *} \\
(0.011)\end{array}$ & & $\begin{array}{l}0.043^{* * *} \\
(0.010)\end{array}$ & & $\begin{array}{c}0.041 * * * \\
(0.010)\end{array}$ \\
\hline (No education) & $-\cdots$ & & -- & & - & -- & \\
\hline Primary education & $\begin{array}{c}0.238 * *: k \\
(0.055)\end{array}$ & & $\begin{array}{l}0.105^{* *} \\
(0.052)\end{array}$ & & $\begin{array}{c}0.078 \\
(0.051)\end{array}$ & $\begin{array}{c}0.056 \\
(0.052)\end{array}$ & \\
\hline Secondary + education & $\begin{array}{l}1.023 * * * * \\
(0.116)\end{array}$ & & $\begin{array}{c}0.479^{* * *} \\
(0.120)\end{array}$ & & $\begin{array}{c}0.431 * * * \\
(0.118)\end{array}$ & $\begin{array}{c}0.394 * * * \\
(0.118)\end{array}$ & \\
\hline \multicolumn{8}{|l|}{ Husband's Education } \\
\hline Years & $\begin{array}{c}0.083^{* * *} \\
(0.008)\end{array}$ & & $\begin{array}{c}0.035^{* * *} \\
(0.009)\end{array}$ & & $\begin{array}{l}0.030^{* * *} \\
(0.009)\end{array}$ & & $\begin{array}{c}0.029 * * * \\
(0.009)\end{array}$ \\
\hline (No education) & $\ldots$ & &.- & & - & - & \\
\hline Primary education & $\begin{array}{c}0.184 * * * \\
(0.057)\end{array}$ & & $\begin{array}{c}0.055 \\
(0.055)\end{array}$ & & $\begin{array}{c}0.030 \\
(0.054)\end{array}$ & $\begin{array}{c}0.023 \\
(0.054)\end{array}$ & \\
\hline Secondary education & $\begin{array}{c}0.782^{* * *} \\
(0.104)\end{array}$ & & $\begin{array}{c}0.347 * * * \\
(0.106)\end{array}$ & & $\begin{array}{c}0.295 * * * \\
(0.104)\end{array}$ & $\begin{array}{c}0.296 * * * \\
(0.104)\end{array}$ & \\
\hline Post-secondary education & $\begin{array}{c}1.654 * * * \\
(0.265)\end{array}$ & & $\begin{array}{c}0.867^{* * *} \\
(0.259)\end{array}$ & & $\begin{array}{c}0.805^{* * *} \\
(0.253)\end{array}$ & $\begin{array}{c}0.797 * * * \\
(0.253)\end{array}$ & \\
\hline \multicolumn{8}{|l|}{ Expenditure Per Capita } \\
\hline Quetzals per month & $\begin{array}{c}0.015^{* * *} \\
(0.002)\end{array}$ & & $\begin{array}{c}0.008^{* * *} \\
(0.002)\end{array}$ & & $\begin{array}{c}0.007^{* * *} \\
(0.002)\end{array}$ & $\begin{array}{c}0.007 * * * \\
(0.002)\end{array}$ & $\begin{array}{c}0.007 * * * \\
(0.002)\end{array}$ \\
\hline
\end{tabular}

The parameter estimates within the boxes refer to models in which mother's education and husband's education are treated, one at a time, as continuous variables. 
(Table 5 continued from previous page)

\begin{tabular}{|c|c|c|c|c|c|c|c|}
\hline $\begin{array}{l}\text { COMMUNITY VARIABLES } \\
\text { Public Health Infrastructure }\end{array}$ & Model $1^{2}$ & Model 2 & Model 3 & $\begin{array}{c}\text { Model } 4 \\
\text { ma* } \\
\text { ma* }\end{array}$ & Model 5 & Model 6 & Model 7 \\
\hline$\%$ hhs with tap water inside & $\begin{array}{l}2.385^{* * * *} \\
(0.589)\end{array}$ & & & $\begin{array}{l}1.813^{* * *} \\
(0.584)\end{array}$ & & $\begin{array}{l}1.232^{* *} \\
(0.499)\end{array}$ & $\begin{array}{l}1.151^{* *} \\
(0.507)\end{array}$ \\
\hline$\%$ hhs with toilet inside & $\begin{array}{l}1.993 * * * \\
(0.418)\end{array}$ & & & $\begin{array}{c}-1.559 * * \\
(0.574)\end{array}$ & & $\begin{array}{l}-1.466^{* * *} \\
(0.494)\end{array}$ & $\begin{aligned}-1.352^{* * *} & (0.501)\end{aligned}$ \\
\hline (No Public dumpsite) & - & & & $-\infty$ & & -- & -- \\
\hline $\begin{array}{l}\text { Public dumpsite in the community } \\
\text { Modernization }\end{array}$ & $\begin{array}{c}0.385 \\
(0.267)\end{array}$ & & & $\begin{array}{l}0.343^{* *} \\
(0.170)\end{array}$ & & $\begin{array}{l}0.310^{* *} \\
(0.145)\end{array}$ & $\begin{array}{l}0.318 * * \\
(0.147)\end{array}$ \\
\hline$\%$ hhs with TV & $\begin{array}{c}1.268^{* * *} \\
(0.281)\end{array}$ & & & $\begin{array}{c}1.259 * * * \\
(0.267)\end{array}$ & & $\begin{array}{l}0.769 * * * \\
(0.229)\end{array}$ & $\begin{array}{c}0.748^{* * *} \\
(0.233)\end{array}$ \\
\hline$\%$ literate women & $\begin{array}{c}1.671^{* * *} \\
(0.368)\end{array}$ & & & $\begin{array}{l}0.712^{*} \\
(0.334)\end{array}$ & & $\begin{array}{c}0.464 \\
(0.289) \\
\#\end{array}$ & $\begin{array}{c}0.330 \\
(0.290) \\
\#\end{array}$ \\
\hline $\begin{array}{l}\text { (No Paved road) } \\
\text { Paved road }\end{array}$ & $\begin{array}{c}-- \\
-0.018 \\
(0.324)\end{array}$ & & & $\begin{array}{c}-0.050 \\
(0.163)\end{array}$ & & $\begin{array}{c}\overline{0} \\
0.037 \\
(0.141)\end{array}$ & $\begin{array}{c}-\overline{0} \\
0.029 \\
(0.143)\end{array}$ \\
\hline Distance to the nearest market & $\begin{array}{l}-0.011 \\
(0.008)\end{array}$ & & & $\begin{array}{c}-0.012^{* *} \\
(0.006)\end{array}$ & & $\begin{array}{c}0.005 \\
(0.005)\end{array}$ & $\begin{array}{c}0.004 \\
(0.005)\end{array}$ \\
\hline (No Commercial farms/Plantations) & -- & & & -. & & .. & - \\
\hline Commercial farms/Plantations & $\begin{array}{c}0.679^{* * *} \\
(0.138)\end{array}$ & & & $\begin{array}{l}0.174^{*} \\
(0.101)\end{array}$ & & $\begin{array}{c}0.103 \\
(0.095)\end{array}$ & $\begin{array}{c}0.113 \\
(0.097)\end{array}$ \\
\hline Total population ${ }^{\mathbf{b}}$ & $\begin{array}{l}-0.012 \\
(0.038)\end{array}$ & & & $\begin{array}{c}-0.090^{* * *} \\
(0.025)\end{array}$ & & $\begin{array}{l}-0.055^{* * *} \\
(0.021)\end{array}$ & $\begin{array}{c}-0.057 * * * \\
(0.022)\end{array}$ \\
\hline (No Bank/Rural cooperative) & - & & & $\ldots$ & & -- & -- \\
\hline Bank/Rural cooperative & $\begin{array}{l}0.323^{* *} \\
(0.157)\end{array}$ & & & $\begin{array}{l}-0.055 \\
(0.087)\end{array}$ & & $\begin{array}{r}-0.056 \\
(0.074)\end{array}$ & $\begin{array}{l}-0.058 \\
(0.075)\end{array}$ \\
\hline Food Prices (quetzals/ounce) & & & & & & & \\
\hline Rice & $\begin{array}{l}-0.167 \\
(0.328)\end{array}$ & & & $\begin{array}{c}0.110 \\
(0.185)\end{array}$ & & $\begin{array}{l}-0.018 \\
(0.159)\end{array}$ & $\begin{array}{c}0.000 \\
(0.162)\end{array}$ \\
\hline Beans & $\begin{array}{l}-0.040 \\
(0.163)\end{array}$ & & & $\begin{array}{c}0.019 \\
(0.094)\end{array}$ & & $\begin{array}{c}0.132 \\
(0.085)\end{array}$ & $\begin{array}{c}0.137 \\
(0.086)\end{array}$ \\
\hline Corn & $\begin{array}{l}-0.020 \\
(0.017)\end{array}$ & & & $\begin{array}{c}0.749 \\
(0.459)\end{array}$ & & $\begin{array}{c}0.321 \\
(0.403)\end{array}$ & $\begin{array}{c}0.341 \\
(0.410)\end{array}$ \\
\hline Sugar & $\begin{array}{c}2.050 \\
(1.130)\end{array}$ & & & $\begin{array}{l}-0.393 \\
(0.936)\end{array}$ & & $\begin{array}{l}-0.509 \\
(0.796)\end{array}$ & $\begin{array}{l}-0.473 \\
(0.809)\end{array}$ \\
\hline Fologicl Charestarictios & $\begin{array}{l}1.879^{* *} \\
(0.922)\end{array}$ & & & $\begin{array}{c}0.866 \\
(0.642)\end{array}$ & & $\begin{array}{c}0.848 \\
(0.550)\end{array}$ & $\begin{array}{c}0.789 \\
(0.560) \\
\text { \#\# }\end{array}$ \\
\hline $\begin{array}{r}\text { Ecological Characteristics } \\
\text { (Altitude }<1500 \text { meters) }\end{array}$ & -- & & & - & & - & + \\
\hline Altitude $1500-2500$ meters & $\begin{array}{l}-0.517^{* * *} \\
(0.150)\end{array}$ & & & $\begin{array}{l}-0.310^{* * * *} \\
(0.114)\end{array}$ & & $\begin{array}{c}-0.273^{* * *} \\
(0.097)\end{array}$ & $\begin{array}{c}-0.291 * * * \\
(0.099)\end{array}$ \\
\hline $\begin{array}{c}\text { Altitude }>2500 \\
\text { Health Care Services }\end{array}$ & $\begin{array}{l}-0.920 * * * \\
(0.183)\end{array}$ & & & $\begin{array}{c}-0.608^{* * *} \\
(0.142) \\
\end{array}$ & & $\begin{array}{c}-0.453^{* * * *} \\
(0.127)\end{array}$ & $\begin{array}{c}-0.466^{* * *} \\
(0.128)\end{array}$ \\
\hline $\begin{array}{l}\text { (No Private HCF in community) } \\
\text { Private HCF in community }\end{array}$ & $\begin{array}{c}-\overline{-} \\
0.0003 \\
(0.163)\end{array}$ & & . & $\begin{array}{c}0.016 \\
(0.110)\end{array}$ & & $\begin{array}{c}-\overline{-} \\
-0.018 \\
(0.093)\end{array}$ & $\begin{array}{c}-\overline{-} \\
-0.022 \\
(0.095)\end{array}$ \\
\hline $\begin{array}{l}\text { (No Gover. HCF in community) } \\
\text { Government HCF in community }\end{array}$ & $\begin{array}{c}0.356^{* *} \\
(0.159)\end{array}$ & & & $\begin{array}{c}0.236^{* *} \\
(0.101)\end{array}$ & & $\begin{array}{c}0.177^{* *} \\
(0.086)\end{array}$ & $\begin{array}{c}0.167^{*} \\
(0.085)\end{array}$ \\
\hline Number of doctors within $20 \mathrm{kms}$ & $\begin{array}{c}0.125^{* * *} \\
(0.044)\end{array}$ & & & $\begin{array}{l}0.108^{* * *} \\
(0.029)\end{array}$ & & $\begin{array}{l}0.059^{* *} \\
(0.026)\end{array}$ & $\begin{array}{l}0.052 * * \\
(0.026)\end{array}$ \\
\hline
\end{tabular}

Omitted categories are shown in parentheses.

*P-Value $<0.1 ;{ }^{* *} \mathrm{P}$-Value $<0.05 ; * * * \mathrm{P}$-Value $<0.01$

Jointly significant at the 5\% level; Jointly significant at the $1 \%$ level.

${ }^{a}$ Models with only one variable at a time. ${ }^{b}$ Mean-centered. 
TABLE 6: RANDOM COEFFICIENTS, INTRA-CLUSTER CORRELATION AND VARIANCE DECOMPOSITION

\begin{tabular}{|c|c|c|c|c|c|c|c|}
\hline & Null Model ${ }^{2}$ & Model 2 & Model 3 & Model 4 & Model 5 & Model 6 & Model 7 \\
\hline & \multicolumn{7}{|c|}{ Random Effects } \\
\hline$\sigma_{c}^{2}$ & $0.365^{* * *}$ & $\begin{array}{c}0.357^{* * *} \\
(2.2 \%)\end{array}$ & $\begin{array}{l}0.120^{* * *} \\
(67.1 \%)\end{array}$ & $\begin{array}{c}0.040^{* * *} \\
(89.0 \%)\end{array}$ & $\begin{array}{l}0.120^{* * *} \\
(67.1 \%)\end{array}$ & $\begin{array}{c}0.025 * * * \\
(93.2 \%)\end{array}$ & $\begin{array}{l}0.027^{* * *} \\
(92.6) \%\end{array}$ \\
\hline$\chi_{1}^{2}$ & 359.8 & 383.1 & 104.4 & 20.6 & 108.8 & 12.5 & 14.6 \\
\hline$\sigma_{f}^{2}$ & $0.372^{* * *}$ & $\begin{array}{c}0.338^{* * *} \\
(9.1 \%)\end{array}$ & $\begin{array}{c}0.234^{* * *} \\
(37.1 \%)\end{array}$ & $\begin{array}{c}0.372^{* * *} \\
(0.0 \%)\end{array}$ & $\begin{array}{l}0.210^{* * *} \\
(43.5 \%)\end{array}$ & $\begin{array}{l}0.208^{* * *} \\
(44.1 \%)\end{array}$ & $\begin{array}{l}0.208^{* * *} \\
(44.1 \%)\end{array}$ \\
\hline$\chi_{1}^{2}$ & 111.2 & 103.2 & 56.5 & 111.8 & 50.43 & 49.9 & 49.9 \\
\hline \multirow[t]{2}{*}{$\sigma_{i}^{2}$} & 0.984 & $\begin{array}{c}0.971 \\
(1.3 \%)\end{array}$ & $\begin{array}{c}0.977 \\
(0.7 \%)\end{array}$ & $\begin{array}{c}0.984 \\
(0.0 \%)\end{array}$ & $\begin{array}{c}0.962 \\
(2.2 \%)\end{array}$ & $\begin{array}{c}0.962 \\
(2.2 \%)\end{array}$ & $\begin{array}{c}0.961 \\
(2.3 \%)\end{array}$ \\
\hline & \multicolumn{7}{|c|}{ Intra-Cluster Correlation } \\
\hline$\rho_{c}$ & 0.212 & 0.214 & 0.090 & 0.029 & 0.093 & 0.021 & 0.023 \\
\hline \multirow[t]{2}{*}{$\rho_{\mathbf{f}}$} & 0.428 & 0.417 & 0.266 & 0.295 & 0.255 & 0.195 & 0.196 \\
\hline & \multicolumn{7}{|c|}{ Variance Decomposition } \\
\hline Community & 21.2 & 21.4 & 9.0 & 2.9 & 9.3 & 2.1 & 2.3 \\
\hline Family & 21.6 & 20.3 & 17.6 & 26.6 & 16.2 & 17.4 & 17.4 \\
\hline Child & 57.2 & 58.3 & 73.4 & 70.5 & 74.5 & 80.5 & 80.4 \\
\hline
\end{tabular}

In brackets is the proportion of the overall variance (null model) explained by the covariates of the index model.

${ }^{\text {a }}$ Model with no covariates.

$* * * \mathrm{P}$-value $<0.01$. 
FIGURE 3: BOX-PLOTS OF COMMUNITY-LEVEL RESIDUALS FROM REDUCEDFORM MODELS*

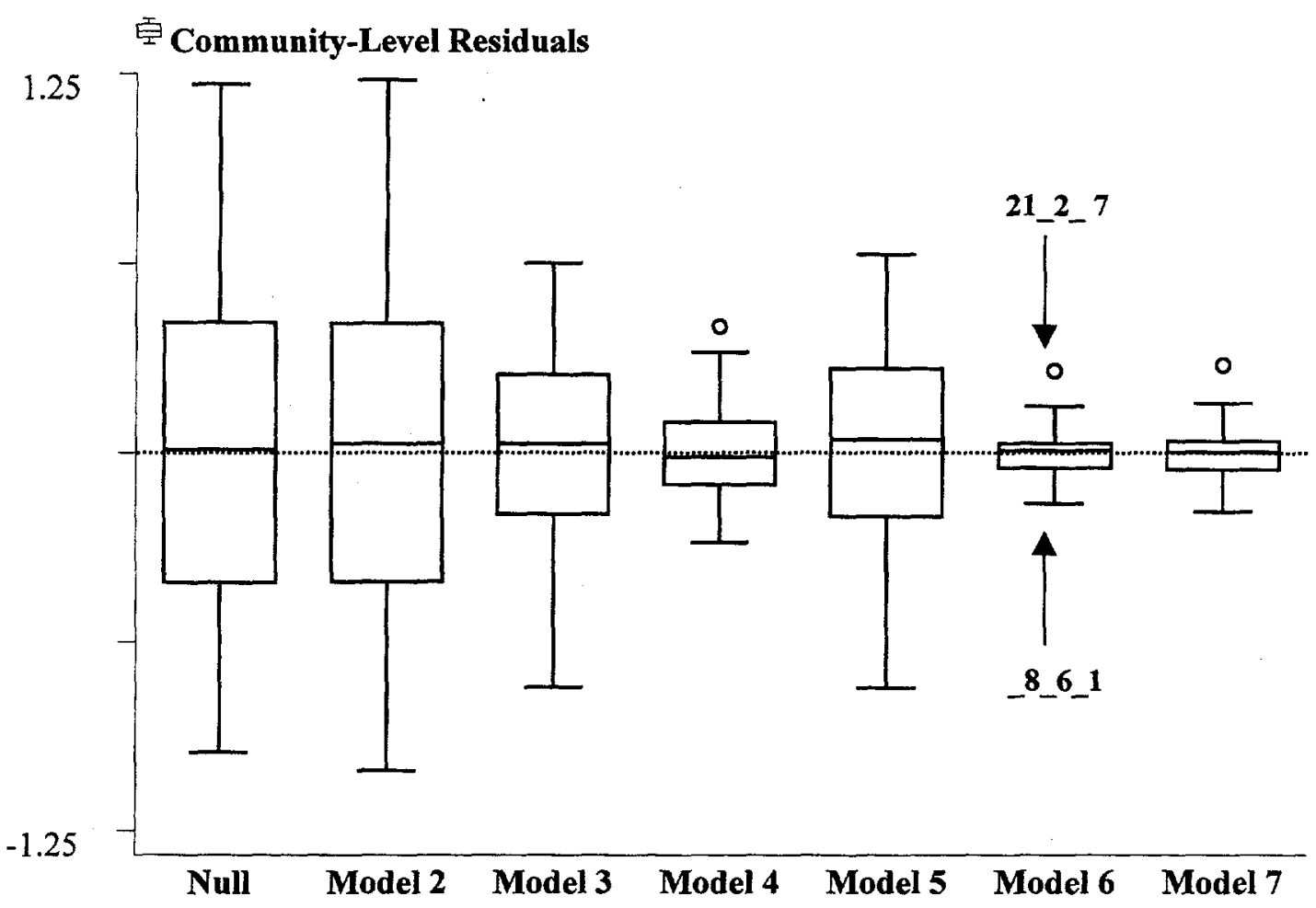

*Community-level residuals are defined as predicted minus observed outcomes 


\begin{tabular}{|c|c|c|c|c|}
\hline & \multicolumn{2}{|c|}{$\begin{array}{l}\text { Covariate included in } \\
\text { reference model }\end{array}$} & \multicolumn{2}{|c|}{$\begin{array}{l}\text { Covariate removed from } \\
\text { full model }\end{array}$} \\
\hline & $\sigma_{\mathrm{c}}^{2}$ & $\begin{array}{c}\% \\
\text { Reduction }\end{array}$ & $\sigma_{c}^{2}$ & $\begin{array}{c}\% \\
\text { Increase }\end{array}$ \\
\hline Reference Model $^{2}$ & 0.365 & & & \\
\hline \multicolumn{5}{|l|}{ HOUSEHOLD VARIABLES } \\
\hline Etnnicity (2 D.F.) & 0.236 & 35.3 & 0.025 & 0.0 \\
\hline Mother's height (1 D.F.) & 0.210 & 34.5 & 0.037 & 48.0 \\
\hline Mother's education (2 D.F.) & 0.296 & 18.9 & 0.026 & 4.0 \\
\hline Husband's education ( 3 D.F.) & 0.324 & 11.2 & 0.025 & 0.0 \\
\hline Expenditure per capita (3 D.F.) & 0.316 & 13.4 & 0.028 & 12.0 \\
\hline \multicolumn{5}{|l|}{ COMMUNITY VARIABLES } \\
\hline \multicolumn{5}{|l|}{ Public Health Infrastructure } \\
\hline$\%$ hhs with tap water inside (1 D.F.) & 0.286 & 21.6 & 0.032 & 28.0 \\
\hline$\%$ hhs with toilet inside ( 1 D.F.) & 0.258 & 29.3 & 0.033 & 32.0 \\
\hline Public dumpsite in the community (1 D.F.) & 0.353 & 3.3 & 0.029 & 16.0 \\
\hline \multicolumn{5}{|l|}{ Modernization } \\
\hline$\%$ hhs with TV ( 1 D.F.) & 0.263 & 27.9 & 0.036 & 44.0 \\
\hline$\%$ literate women (1 D.F.) & 0.263 & 27.9 & 0.028 & 12.0 \\
\hline \multicolumn{5}{|l|}{ Economic Structure } \\
\hline Paved road (1 D.F.) & 0.365 & 0.0 & 0.025 & 0.0 \\
\hline Distance to the nearest market (1 D.F.) & 0.353 & 3.3 & 0.027 & 8.0 \\
\hline Commercial farms/Plantations ( 1 D.F.) & 0.254 & 30.4 & 0.026 & 4.0 \\
\hline Total population (1 D.F.) & 0.365 & 0.0 & 0.032 & 28.0 \\
\hline Bank/Rural cooperative ( 1 D.F.) & 0.339 & 7.1 & 0.026 & 4.0 \\
\hline \multicolumn{5}{|l|}{ Food Prices } \\
\hline All (5 D.F.) & 0.321 & 12.1 & 0.032 & 28.0 \\
\hline \multicolumn{5}{|l|}{ Ecological Characteristics } \\
\hline Altitude (2 D.F.) & 0.239 & 42.5 & 0.041 & 64.0 \\
\hline \multicolumn{5}{|l|}{ Health Care Services } \\
\hline Private HCF in community (1 D.F.) & 0.365 & 0.0 & 0.025 & 0.0 \\
\hline Government HCF in community (1 D.F.) & 0.336 & 7.9 & 0.029 & 16.0 \\
\hline Number of doctors within $20 \mathrm{kms}$ ( 1 D.F.) & 0.317 & 13.2 & 0.032 & 28.0 \\
\hline Full Model ${ }^{\mathbf{b}}$ & & & 0.025 & \\
\hline
\end{tabular}

${ }^{\mathrm{a}}$ Model with age and sex

${ }^{b}$ Model 6 
TABLE 8: INTRA-FAMILY CORRELATION*

Covariate included in null model Covariate removed from full model

$\begin{array}{cccc}\rho_{\mathrm{f}} & \begin{array}{c}\% \\ \text { Reduction }\end{array} & \rho_{\mathrm{f}} & \begin{array}{c}\% \\ \text { Increase }\end{array}\end{array}$

Reference Model $^{\mathrm{a}} \quad 0.338$

\section{HOUSEHOLD VARIABLES}

Ethnicity (2 D.F.)

$\begin{array}{lrrr}0.320 & 5.3 & 0.212 & 8.7 \\ 0.254 & 24.9 & 0.264 & 35.4 \\ 0.309 & 8.6 & 0.213 & 9.2 \\ 0.296 & 12.4 & 0.215 & 10.3 \\ 0.309 & 8.6 & 0.215 & 10.3\end{array}$

Full Model $^{\mathrm{b}}$

0.195

$* \rho_{f}=\left(\sigma_{c}^{2}+\sigma_{f}^{2}\right) /\left(\sigma_{c}^{2}+\sigma_{f}^{2}+\sigma_{i}^{2}\right)$

${ }^{a}$ Model with age and sex

${ }^{\mathrm{b}}$ Model 6 
TABLE 9: RANDOM-COEFFICIENTS MODELS: LIKELIHOOD-RATIO TESTS FOR RANDOM EFFECTS OF EDUCATION AND EXPENDITURE

\begin{tabular}{lccc}
\hline & Mother's Education & Husband's Education & Expenditure Per Capita \\
\hline$\chi^{2}{ }_{2}$ & 0.00 & 4.64 & 2.10 \\
P-Value & 1.000 & 0.098 & 0.350 \\
\hline
\end{tabular}


TABLE 7. 2: CROSS-LEVEL INTERACTIONS BETWEEN MOTHER'S EDUCATION, HUSBAND'S EDUCATION, EXPENDITURE PER CAPITA AND COMMUNITY CHARACTERISTICS

\begin{tabular}{|c|c|c|c|c|c|c|}
\hline \multirow{4}{*}{ Constant } & \multicolumn{2}{|c|}{ Mother's education } & \multicolumn{2}{|c|}{ Husband's education } & \multicolumn{2}{|c|}{ Expenditure pc } \\
\hline & Main Effect & & Main Effect & & Main Effect & \\
\hline & $-2.720^{* *}$ &.- & $-2.337^{* *}$ & -- & -1.263 & - \\
\hline & $(1.354)$ & - & $(1.288)$ & - & (1.803) & - \\
\hline \multicolumn{7}{|l|}{ CHILD VARLABLES } \\
\hline \multicolumn{7}{|l|}{ Age of the child } \\
\hline \multirow[t]{2}{*}{ Age (months) } & $-0.015^{* * *}$ & - & $-0.015 * * *$ & - & $-0.015^{* * *}$ & -- \\
\hline & $(0.002)$ & -- & $(0.002)$ & -- & $(0.002)$ & -- \\
\hline Age $*$ dummy & $-0.030 * * *$ & -- & $-0.030 * * *$ & - & $-0.030 * * *$ & -- \\
\hline$($ dummy $=1$ if age $<24)$ & $(0.005)$ & -- & $(0.005)$ & -- & $(0.005)$ & -- \\
\hline \multicolumn{7}{|l|}{ Sex } \\
\hline (Female) & -- & -- & - & - & & - \\
\hline \multirow[t]{2}{*}{ Male } & 0.018 & -- & 0.013 & -- & 0.018 & - \\
\hline & $(0.044)$ & -- & $(0.043)$ & -- & $(0.044)$ & - \\
\hline \multicolumn{7}{|l|}{ HOUSEHOLD VARIABLES } \\
\hline \multicolumn{7}{|l|}{ Ethnicity } \\
\hline (Ladino) & -- & -- & - & -. & & -- \\
\hline \multirow[t]{2}{*}{ Indigenous \& Spanish } & -0.114 & -- & -0.097 & 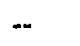 & -0.132 & -- \\
\hline & $(0.082)$ & -- & $(0.079)$ & -- & $(0.081)$ & - \\
\hline \multirow[t]{2}{*}{ Indigenous \& No Spanish } & $-0.227 * *$ & -- & $-0.207 * *$ & -- & $-0.240^{* *}$ & -. \\
\hline & $(0.101)$ & -- & $(0.098)$ & -- & $(0.100)$ & -- \\
\hline \multicolumn{7}{|l|}{ Mother's Height } \\
\hline \multirow[t]{2}{*}{ Cms. } & $0.055^{* * *}$ & -- & $0.056^{* * *}$ & -- & $0.054 * * *$ & - \\
\hline & $(0.005)$ & -- & $(0.005)$ & -- & $(0.005)$ & -- \\
\hline \multicolumn{7}{|l|}{ Mother's Education } \\
\hline \multirow[t]{2}{*}{ Years } & 0.088 & -- & $0.036^{* * *}$ &.- & $0.039 * * *$ & - \\
\hline & $(0.338)$ & -- & $(0.010)$ & -- & $(0.010)$ & -- \\
\hline \multicolumn{7}{|l|}{ Husband's Education } \\
\hline \multirow[t]{2}{*}{ Years } & $0.029 * * *$ & -- & -0.205 & -- & $0.029 * * *$ & -- \\
\hline & $(0.009)$ & -- & $(0.281)$ & -- & $(0.009)$ & -- \\
\hline \multicolumn{7}{|l|}{ Expenditure Per Capita } \\
\hline \multirow[t]{2}{*}{ Quetzals per month } & $0.007 * * *$ & -- & $0.007^{* * *}$ & -- & -0.040 & -- \\
\hline & $(0.002)$ & -- & $(0.002)$ & -- & $(0.061)$ & -- \\
\hline
\end{tabular}




\section{COMMUNITY VARIABLES}

Public Health Infrastructure

$\%$ hhs with tap water inside

$\%$ hhs with toilet inside

No Public dumpsite)

Public dumpsite in the community

Modernization

$\%$ hhs with TV

$\%$ literate women

\section{Economic Structure}

(No Paved road)

Paved road

Distance to the nearest market

(No Commercial farms/Plantations)

Total population

(No Bank/Rural cooperative)

Bank/Rural cooperative

Food Prices (quetzals/ounce)

Rice

Beans

Corn

Sugar

Salt

\section{Ecological Characteristics}

(Altitude $<1500$ meters)

Altitude $1500-2500$ meters

Altitude $>2500$

\section{Health Care Services}

(No Private HCF in community)

No Gover. HCF in community)

Government HCF in community

Number of doctors within $20 \mathrm{kms}$

\section{Mother's education}

Main Effect

Interaction

$1.291^{*}$

(0.621)

$-1.685^{* *}$

$(0.607)$

$-0.061$

(0.112)

-.

0.078

$(0.128)$

$0.302 *$

$0 . \overline{022}$

(0.176)

0.022

$0.678 * *$

$(0.280)$

0.499

$(0.345)$

$(0.046)$

0.011

$(0.069)$

$-0.011$

(0.110)

0.001

(0.159)

0.001

$(0.006)$

$0 . \overline{0} 1$

$(0.042)$

0.001

$0 . \overline{146}$

$(0.001)$

0.146

$-0.050 *$

0.001

$(0.026)$

(0.029)

$-0.003$

(0.006)

$-0.153$

$-0.153^{*}$

$(0.089)$

$0.038^{*}$

$(0.022)$

$\begin{array}{ll}-0.098 & 0.043\end{array}$

$(0.187)$

0.138

$(0.050)$

$(0.099)$

0.270

$(0.470)$

0.087

(0.976)

0.212

(0.680)

\subsection{3}

$(0.027)$

$-0.026$

(0.111)

$-0.197$

(0.236)

0.189

0.189
$(0.170)$

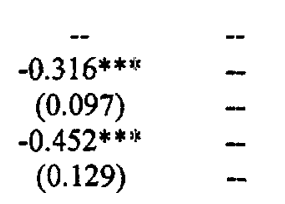

$-\overline{111} \quad-$

$-0.111$

(0.109)

0.046
$(0.031)$

$0 . \overline{145}$

(0.105)

$0.057^{*}$

$(0.032)$
$0 . \overline{001}$

$(0.029)$

0.000

$(0.007)$
Husband's education

Main Effect Interaction

$\begin{array}{cc}0.620 & 0.177 \\ (0.611) & (0.100) \\ -1.134 * & -0.177 \\ (0.615) & (0.115) \\ -- & -- \\ 0.457^{* *} & -0.009 \\ (0.196) & (0.039) \\ & \\ 0.800^{* * *} & -0.022 \\ (0.289) & (0.056) \\ 0.362 & 0.093 \\ (0.350) & (0.078)\end{array}$

$\begin{array}{cc}1.560^{* * *} & -0.014 \\ (0.790) & (0.022) \\ -2.356 * * * & 0.040^{*} \\ (0.782) & (0.024) \\ -- & -- \\ 0.280 & 0.002 \\ (0.229) & (0.009) \\ & \\ 0.884 * * & -0.006 \\ (0.364) & (0.012) \\ 0.313 & 0.000 \\ (0.454) & (0.016)\end{array}$

0.108

$(0.164)$

$-0.002$

$(0.006$

$-$

$0.214 *$

$(0.118)$

$-0.037$

$(0.027)$

$--$

$-0.173 *$

$(0.092)$

$-\overline{0.017}$

$(0.033)$

0.001

$(0.001)$

$-$

$(0.023)$

$-0.006$

$(0.005)$

$0 . \overline{0}$

$(0.018)$

0.050

$(0.190)$

$-0.011$

$(0.104)$

$0.816^{*}$

(0.474)

$-0.322$

$(0.964)$

0.300

(0.666)

$-0.015$

$(0.039)$

0.054 *

$(0.032)$

$-0.109$

(0.087)

0.003

$(0.200)$

0.194

$(0.128)$

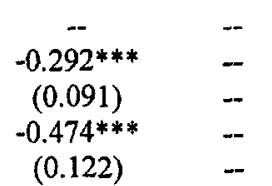

$-$

$-0.027$

$0 . \overline{0}$

$(0.110)$

(0.024)

0.091

$(0.106)$

0.016

$(0.032)$

\section{$-$}

$0.076 * * *$

$0.016 * * *$

$(0.007)$ $\begin{array}{ll}-- & --\end{array}$

$\begin{array}{ll}-0.044 & 0.003\end{array}$

$(0.219) \quad(0.007)$

$0.003 \quad 0.000$

$(0.007) \quad(0.000)$

$\overline{--} \quad \overline{243}$

$(0.152) \quad(0.005)$

$\begin{array}{ll}-0.025 & -0.001\end{array}$

$(0.034) \quad(0.001)$

$-0.002 \quad-0.003$

$(0.117) \quad(0.004)$

$-0.287 \quad 0.015^{*}$

$(0.247) \quad(0.009)$

$0.124 \quad 0.001$

$(0.135) \quad(0.005)$

$(0.575) \quad(0.019)$

$\begin{array}{ll}-0.740 & 0.009\end{array}$

$(1.319) \quad(0.046)$

$0.229 \quad 0.023$

$(0.884) \quad(0.030)$
Commercial farms/Plantations

Private HCF in community

$-0.015$

$0.338 \quad-0.002$

*P-Value $<0.1 ;{ }^{* *}$ P-Value $<0.05 ; * * *$ P-Value $<0.01$.

\#\# Jointly significant at the 1 percent level. 
TABLE 11: INTERACTIONS WITH ETHNICITY/LANGUAGE

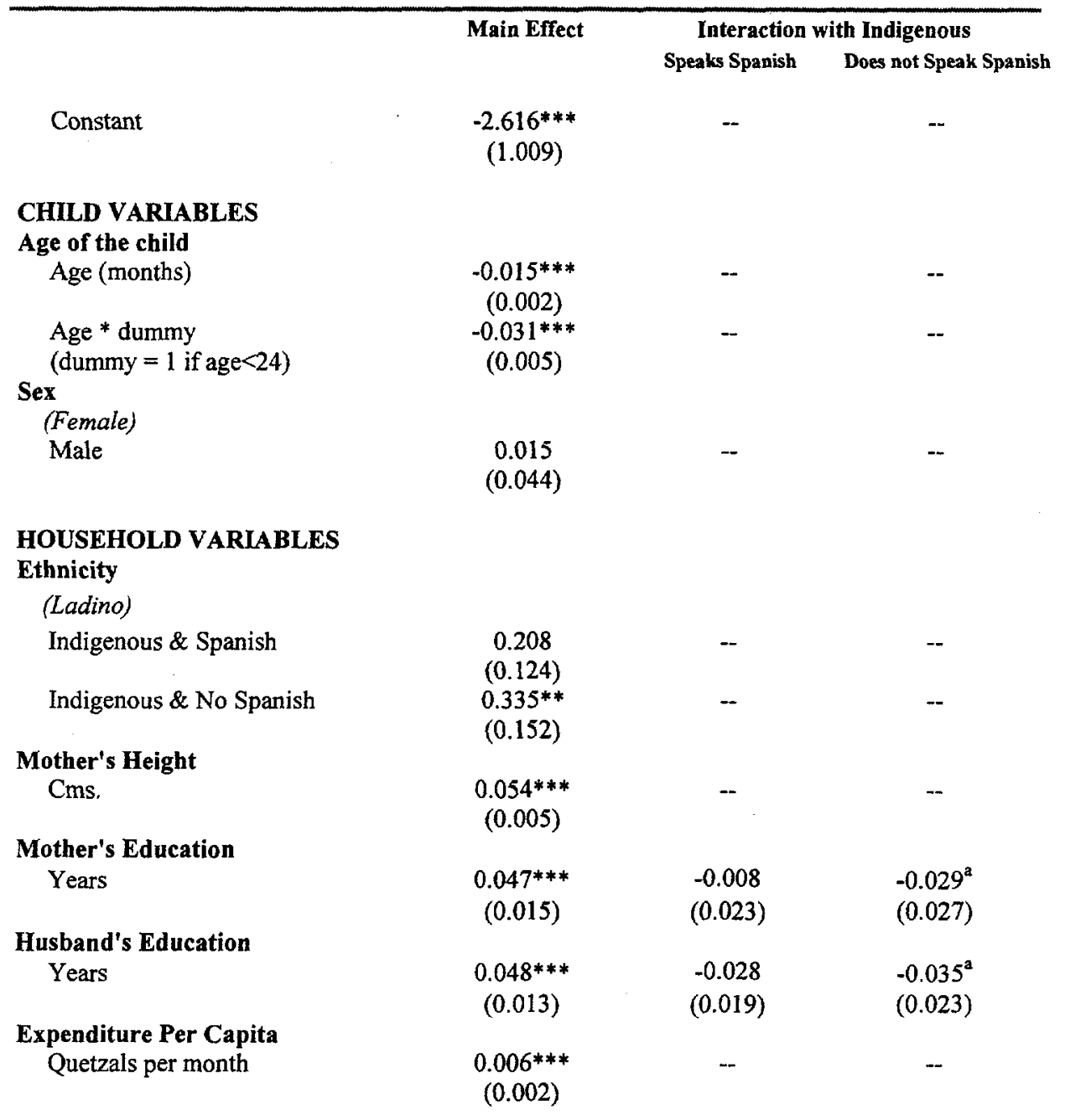

${ }^{\mathrm{a}}$ The likelihood ratio tests on the joint significance of both coefficients is 5.96 (P-value $\equiv 0.051$ ). Moreover, each coefficient is significant at the $1 \%$ level in Step 1. 
Main Effect

COMMUNITY VARIABLES

Public Health Infrastructure

$\%$ hhs with tap water inside

$\%$ hhs with toilet inside

(No Public dumpsite)

Public dumpsite in the community

\section{Modernization}

$\%$ hhs with TV

$\%$ literate women

\section{Economic Structure}

No Paved road)

Paved road

Distance to the nearest market

(No Commercial farms/Plantations)

Commercial farms/Plantations

Total population

(No Bank/Rural cooperative)

Bank/Rural cooperative

\section{Food Prices (quetzals/ounce)}

Rice

Beans

Corn

Sugar

Salt

\section{Ecological Characteristics}

(Altitude $<1500$ meters)

Altitude $1500-2500$ meters

Altitude $>2500$

\section{Health Care Services}

(No Private HCF in community)

Private HCF in community

(No Gover. HCF in community)

Government HCF in community

Number of doctors within $20 \mathrm{kms}$
$1.521 * * *$

$(0.468)$

$-1.996 * * *$

$(0.478)$

$0.348^{* * *}$

$(0.133)$

$0.832 * * *$

$(0.209)$

0.216

$(0.265)$

0.022

$(0.130)$

0.005

(0.004)

0.132

$(0.087)$

$-0.063 * * *$

(0.019)

0.010

$(0.069)$

0.017

(0.14.5)

0.130

$(0.079)$

0.265

$(0.372)$

$-0.505$

(0.733)

0.991

$(0.5: 9)$

$-0.359^{* * *}$

$(0.090)$

$-0.511 * * *$

(0.116)

$-0.035 * * *$

(0.085)

$0.389^{* * * *}$

(0.126)

0.094

(0.029)
Interaction with Indigenous

Speaks Spanish

Does not Speak Spanish 



\section{Policy Research Working Paper Series}

\begin{tabular}{|c|c|c|c|c|}
\hline & Title & Author & Date & $\begin{array}{l}\text { Contact } \\
\text { for paper }\end{array}$ \\
\hline WPS2174 & $\begin{array}{l}\text { Prospective Deficits and the Asian } \\
\text { Currency Crisis }\end{array}$ & $\begin{array}{l}\text { Craig Burnside } \\
\text { Martin Eichenbaum } \\
\text { Sergio Rebelo }\end{array}$ & September 1999 & $\begin{array}{l}\text { E. Khine } \\
37471\end{array}$ \\
\hline WPS2175 & $\begin{array}{l}\text { Sector Growth and the Dual Economy } \\
\text { Model: Evidence from Côte d'lvioire, } \\
\text { Ghana, and Zimbabwe }\end{array}$ & $\begin{array}{l}\text { Niels-Hugh Blunch } \\
\text { Dorte Verner }\end{array}$ & September 1999 & $\begin{array}{l}\text { H. Vargas } \\
37871\end{array}$ \\
\hline WPS2176 & $\begin{array}{l}\text { Fiscal Risks and the Quality of } \\
\text { Fiscal Adjustment in Hungary }\end{array}$ & $\begin{array}{l}\text { Hana Polackova Brixi } \\
\text { Anita Papp } \\
\text { Allen Schick }\end{array}$ & September 1999 & $\begin{array}{l}\text { A. Panton } \\
85433\end{array}$ \\
\hline WPS2177 & $\begin{array}{l}\text { Fiscal Adjustment and Contingent } \\
\text { Government Liabilities: Case Studies } \\
\text { Of the Czech Republic and Macedonia }\end{array}$ & $\begin{array}{l}\text { Hana Polackova Brixi } \\
\text { Hafez Ghanem } \\
\text { Roumeen Islam }\end{array}$ & September 1999 & $\begin{array}{l}\text { A. Panton } \\
85433\end{array}$ \\
\hline WPS2178 & $\begin{array}{l}\text { Nonfarm Income, Inequality, arid Land } \\
\text { In Rural Egypt }\end{array}$ & Richard H. Adams Jr. & September 1999 & $\begin{array}{l}\text { M. Coleridge-Taylor } \\
33704\end{array}$ \\
\hline WPS2179 & $\begin{array}{l}\text { How Child Labor and Child Schooling } \\
\text { Interact with Adult Labor }\end{array}$ & Ranjan Ray & September 1999 & $\begin{array}{l}\text { M. Mason } \\
30809\end{array}$ \\
\hline WPS2180 & $\begin{array}{l}\text { Regulating Privatized Infrastructures } \\
\text { and Airport Services }\end{array}$ & $\begin{array}{l}\text { Ofelia Betancor } \\
\text { Robert Rendeiro }\end{array}$ & September 1999 & $\begin{array}{l}\text { G. Chenet-Smith } \\
36370\end{array}$ \\
\hline WPS2181 & $\begin{array}{l}\text { Privatization and Regulation of the } \\
\text { Seaport Industry }\end{array}$ & $\begin{array}{l}\text { Lourdes Trujillo } \\
\text { Gustavo Nombela }\end{array}$ & September 1999 & $\begin{array}{l}\text { G. Chenet-Smith } \\
36370\end{array}$ \\
\hline WPS2182 & $\begin{array}{l}\text { The Integration of Transition } \\
\text { Economies into the World Trading } \\
\text { System }\end{array}$ & Constantine Michalopoulos & September 1999 & $\begin{array}{l}\text { L. Tabada } \\
36896\end{array}$ \\
\hline WPS2183 & $\begin{array}{l}\text { Market Discipline and Financial } \\
\text { Safety Net Design }\end{array}$ & $\begin{array}{l}\text { Asli Demirgüç-Kunt } \\
\text { Harry Huizinga }\end{array}$ & September 1999 & $\begin{array}{l}\text { K. Labrie } \\
31001\end{array}$ \\
\hline WPS2184 & $\begin{array}{l}\text { Financial Services and the World } \\
\text { Trade Organization: Liberalization } \\
\text { Commitments of the Developing } \\
\text { and Transition Economies }\end{array}$ & Aaditya Mattoo & September 1999 & $\begin{array}{l}\text { L. Tabada } \\
36896\end{array}$ \\
\hline WPS2185 & $\begin{array}{l}\text { Financial Sector Inefficiencies and } \\
\text { Coordination Failures: Implications } \\
\text { for Crisis Management }\end{array}$ & $\begin{array}{l}\text { Pierre-Richard Agénor } \\
\text { Joshua Aizenman }\end{array}$ & September 1999 & $\begin{array}{l}\text { T. Shiel } \\
36317\end{array}$ \\
\hline WPS2186 & $\begin{array}{l}\text { Contagion, Bank Lending Spreads, } \\
\text { and Output Fluctuations }\end{array}$ & $\begin{array}{l}\text { Pierre-Richard Agénor } \\
\text { Joshua Aizenman } \\
\text { Alexander Hoffmaister }\end{array}$ & September 1999 & $\begin{array}{l}\text { T. Shiel } \\
36317\end{array}$ \\
\hline
\end{tabular}


Policy Research Working Paper Series

Title

WPS2187 Who Determines Mexican Trade Policy?

WPS2188 Financial Liberalization and the Capital Account: Thailand, 1988-97
Author

$$
\text { Jean-Marie Grether }
$$$$
\text { Jaime de Melo }
$$

Pedro Alba

Leonardo Hernandez

Daniela Klingebiel

\begin{tabular}{|c|c|c|}
\hline WPS2189 & $\begin{array}{l}\text { Alternative Frameworks for } \\
\text { Providing Financial Services }\end{array}$ & $\begin{array}{l}\text { Stijn Claessens } \\
\text { Daniela Klingebiel }\end{array}$ \\
\hline WPS2190 & $\begin{array}{l}\text { The Credit Channel at Work: Lessons } \\
\text { from the Republic of Korea's Financial } \\
\text { Crisis }\end{array}$ & $\begin{array}{l}\text { Giovanni Ferri } \\
\text { Tae Soo Kang }\end{array}$ \\
\hline WPS2191 & $\begin{array}{l}\text { Can No Antitrust Policy Be Better } \\
\text { Than Some Antitrust Policy? }\end{array}$ & Aaditya Mattoo \\
\hline WPS2192 & $\begin{array}{l}\text { Districts, Spillovers, and Government } \\
\text { Overspending }\end{array}$ & Reza Baqir \\
\hline
\end{tabular}

Date

$\begin{array}{ll}\text { September 1999 } & \text { L. Tabada } \\ & 36896 \\ & \\ \text { September 1999 } & \text { R. Vo } \\ & 33722\end{array}$

September 1999 R. Vo 33722

September 1999 K. Labrie 31001
September $1999 \quad$ L. Tabada 36896

September 1999 S. Devadas 87891 